\title{
AN INTERNATIONAL COMPARISON OF VOTING BY COMMITTEES
}

by Alexander Jung 


\title{
AN INTERNATIONAL COMPARISON OF VOTING BY COMMITTEES '
}

\author{
by Alexander Jung ${ }^{2}$
}
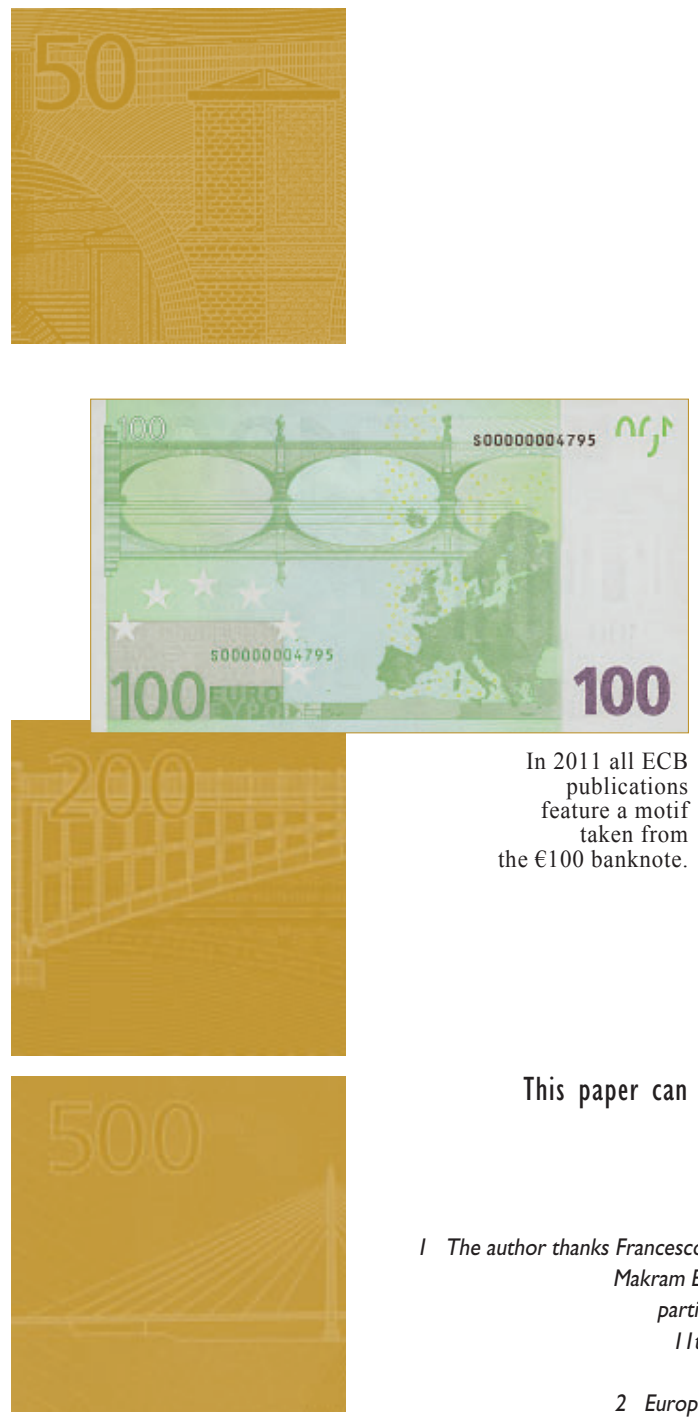

NOTE: This Working Paper should not be reported as representing the views of the European Central Bank (ECB). The views expressed are those of the authors and do not necessarily reflect those of the ECB.

This paper can be downloaded without charge from http://www.ecb.europa.eu or from the Social Science Research Network electronic library at http://ssrn.com/abstract_id $=1932206$.

I The author thanks Francesco Mongelli, Arnab Bhattacharjee, Luca Benati, Jan Marc Berk, Tobias Blattner, Chun-Chih Chen, Mike Mariathasan, Makram El-Shagi, Michael Ehrmann, Christophe Kamps, Jean-Pierre Vidal, Livio Stracca, Peter Welz, an anonymous referee, participants of the 85th Annual conference of the Western Economic Association International and participants of the IIthIWH-CIREQ Macroeconometric Workshop: Causation, Forecasting and Macroeconomics for useful comments. 
(C) European Central Bank, 2011

\section{Address}

Kaiserstrasse 29

60311 Frankfurt am Main, Germany

\section{Postal address}

Postfach 160319

60066 Frankfurt am Main, Germany

Telephone

+496913440

Internet

http://www.ecb.europa.eu

Fax

+496913446000

All rights reserved.

Any reproduction, publication and reprint in the form of a different publication, whether printed or produced electronically, in whole or in part, is permitted only with the explicit written authorisation of the ECB or the author(s).

Information on all of the papers published in the ECB Working Paper Series can be found on the ECB's website, http://www. ecb.europa.eu/pub/scientific/wps/date/ html/index.en.html

ISSN 1725-2806 (online) 


\section{CONTENTS}

Abstract

Non-technical summary

1 Introduction

2 Heterogeneity in the monetary policy process

3 What can be learnt from committees' voting records?

4 An econometric analysis of diversity in committees

4.1 Testing for heterogeneity in monetary policy committees

4.2 Estimating reaction functions with a real-time data base

4.3 Reaction functions for the FOMC, the MPC and the Riksbank's Executive Board

5 Conclusions

Appendix

References

Figures and tables 


\begin{abstract}
This paper provides new empirical evidence on policy-makers' voting patterns on interest rates. Applying (pooled) Taylor-type rules and using real-time information available from published inflation reports and voting records, the paper tests for heterogeneity among committee members in three monetary policy committees: the FOMC, the Bank of England's MPC and the Riksbank's Executive Board. It separately estimates the empirical reaction functions with and without imposing the long-run restriction from the inertia, thereby distinguishing between the short-run and long-run responses of members to incoming information. Unconstrained reaction functions that measure the short-term response show that preference heterogeneity and some diversity of views on the inflation and economic outlook was present in all three committees. By contrast, constrained reaction functions that measure the long-term response find that evidence in favour of preference heterogeneity in all three committees is at best weak. Preference distributions in all three committees were fairly symmetric around the respective mean and diversity of views was only observed in the case of Sweden when including the financial crisis episode. A cluster analysis of the Riksbank's Executive Board, which only comprises internal members, confirms that its members have disperse preferences and views on the transmission mechanism. For the FOMC and for the MPC this analysis suggests that among several background characteristics (membership, background, tenure), membership is a potentially relevant factor that may explain some of the differences in preferences.
\end{abstract}

JEL codes: C23, D72, D83, E58

Keywords: Monetary policy committee, Taylor rule, collective decision-making, voting behavior, pooled regressions, heterogeneous preferences. 


\section{Non-technical summary}

In the deliberations of monetary policy committees, policy-makers may disagree on what constitutes the most appropriate policy response given circumstances. Diversity across policy-makers is an important feature of voting by monetary policy committees. Its occurrence has been attributed to differences in terms of skills, backgrounds and preferences of its members. The literature emphasises the beneficial effects of diverse views in monetary policy committees. Monetary policy committees meet frequently to discuss the economic outlook and its implications for the monetary policy stance. Most committees keep their internal deliberations secret or publish them in an (anonymous) summary form only after intense redrafting. A march towards greater transparency in monetary policy has not changed a widely shared reluctance among policy-makers to reveal their individual preferences on policy rates. Therefore, central bank watchers often have difficulties to observe the full diversity of policy-makers' views expressed in committee deliberations and they often characterise committee members in a rather simplistic manner as "hawks" or "doves".

Some central banks publish (attributed) voting records with detailed information on agreement and dissent by member after the policy meeting. Such voting records are an important source on diversity among policy-makers in committees. Examples of central banks that publish attributed voting records are the Federal Reserve, the Bank of England, and the Swedish Riksbank. Because voting records tend to understate differences in views among members expressed at the meeting, statistics on dissenting cannot be considered to be unbiased indicators of policy preferences. Though, central bank committees with individual accountability (MPC, Riksbank's Executive Board) may have an incentive to reveal more accurate information on member's preferences within the voting records. In the case of the FOMC and other central banks with collective accountability, better sources on diversity can be extracted from transcripts and minutes. They provide more detailed information on diversity of views in the committee, but are at best published with considerable delays of some months or years. Hence, most researchers have used (attributed) voting records for the analysis of preference heterogeneity in a monetary policy committee. This paper uses voting records for three monetary policy committees, the FOMC, the MPC and the Riksbank's Executive Board. 
For the past decade dissenting in the FOMC was infrequent, and the dispersion of Board members' and regional presidents' votes was quite low. For comparison, monetary policy committees of the other central banks considered - the Bank of England's MPC and the Swedish Riksbank's Executive Board have taken their monetary policy decisions in a less consensual manner as indicated by a higher number of members casting a dissent throughout the whole sample. This picture is confirmed when analysing episodes of split interest rates. They were absent for the FOMC over the past decade, whereas for the other committees such episodes existed even though they were rare.

Heterogeneity in policy deliberations is beneficial and is an important element of group decisionmaking. The paper tests for heterogeneity among committee members and identifies several possible sources for its occurrence. Applying (pooled) Taylor-type rules and using real-time information on economic indicators available from published inflation reports, the paper examines to what extent preference heterogeneity and diversity of views among committee members impact on monetary policy decisions in the three monetary policy committees. The usual caveats apply to this analysis. Policymakers set interest rates in real-time and consider various aspects that cannot be captured by means of a simple rule. For example, they typically consult a broad range of indicators and a suite of models in their assessments of inflationary risks. The reaction functions in the present study are therefore used as benchmarks, and it is not assumed that policy-makers de facto would follow a simple rule.

The paper separately estimates the empirical reaction functions with and without imposing the long-run restriction from the inertia, thereby distinguishing between the short-run and long-run responses of members to incoming information. Unconstrained reaction functions that measure the short-term response show that preference heterogeneity and some diversity of views on the inflation and economic outlook was present in all three committees considered. For the FOMC measurable differences of views relate to the output gap but not to the inflation gap. By contrast, during 1998 to 2008, for the two inflation-targeting committees measurable differences of views relate to the inflation forecast or inflation gap but not the output gap. The different behaviour could be attributable to the mandate of the central banks which includes a more explicit concern for economic growth in the case of the Fed. By contrast, constrained reaction functions that measure the long-term response find that evidence in 
favour of preference heterogeneity in all three committees is at best weak. Preference distributions in all three committees were fairly symmetric around the respective mean and diversity of views on the output gap was only observed in the case of Sweden when including the financial crisis episode.

A cluster analysis of the Riksbank's Executive Board, which only comprises internal members, confirms that its members have disperse preferences and views on the transmission mechanism. For the FOMC and for the MPC this analysis suggests that among several background characteristics (membership, background, tenure), membership is a potentially relevant factor that may explain some of the differences in preferences. In the case of the FOMC these differences relate both to preferences and to views on the transmission in the sense that Fed Banks' Presidents have more disperse preferences than the members of the Board of Governors which behave fairly similar. In the case of the MPC, preference heterogeneity was present but similar for internal and external members. Though, when comparing how they react to shocks, it turns out that overall internal members react more aggressively to the inflationary consequences of shocks than external members. 


\section{INTRODUCTION}

In the deliberations of monetary policy committees, policy-makers may disagree on what constitutes the most appropriate policy response given circumstances. Several authors have analyzed the monetary policy process from a theoretical perspective or have provided case studies. Examples include Blinder, Ehrmann, Fratzscher, and de Haan (2008), Gerlach-Kristen (2006), Meyer (2004), Moutot, Jung, and Mongelli (2008) and Sibert (2002). Others have provided quantitative evidence mostly focussing on the FOMC and the Bank of England's MPC. Research by Chappell, Havrilesky and McGregor (1997), Chapell, McGregor, Vermilyea (2005), Meade and Sheets (2002, 2005), Besley, Meads and Surico (2008), Bhattacharjee and Holly (2006), Riboni and Ruge-Murcia $(2008,2010)$ suggest that voting by monetary policy committees is characterized by considerable heterogeneity among policy-makers. This work has contributed to a better understanding of the dynamics in monetary policy committees.

The present paper aims to provide new empirical evidence on policy-makers' voting patterns on interest rates and on their individual preferences. It is related to a small, but growing, literature that estimates reaction functions of members of monetary policy committees. The paper first reviews a host of factors that may explain why members in monetary policy committees may have disperse views on the policy rate. Then it tests for the existence of heterogeneity among policy-makers in three monetary policy committees: the FOMC, the Bank of England's MPC, and the Riksbank's Executive Board. The paper uses a new real-time data base for key economic indicators and information on policy-makers' votes from published voting records. It separately estimates the empirical reaction functions with and without imposing the long-run restriction from the inertia, thereby distinguishing between the short-run and long-run responses of members to incoming information. Unconstrained reaction functions that measure the short-term response show that preference heterogeneity and some diversity of views on the inflation and economic outlook was present in all three committees. By contrast, constrained reaction functions that measure the long-term response find that evidence in favour of preference heterogeneity in all three committees is at best weak. Preference distributions in all three committees were fairly symmetric around the respective mean and diversity of views was only observed in the case of Sweden when including the financial crisis episode. A cluster analysis of the Riksbank's Executive Board, which only comprises internal members, confirms that its members have disperse preferences and views on the transmission mechanism. For the FOMC and for the MPC this analysis suggests that among several 
background characteristics (membership, background, tenure), membership is a potentially relevant factor that may explain some of the differences in preferences.

The paper is organized as follows. Section 2 explains why heterogeneity is an important element of the monetary policy process involving committees. Section 3 provides a descriptive analysis of dispersion in using information contained in committees' voting records. Section 4 uses pooled Taylor-type rules to analyse diversity evident from policy-makers' voting records. It compares evidence for three committees: the FOMC, the MPC and the Riksbank's Executive Board. Section 5 concludes.

\section{HETEROGENEITY IN THE MONETARY POLICY PROCESS}

Decision-making by monetary policy committees can be described as a group decision-making process under uncertainty. Brainard (1967) compares the task of a monetary policy-maker with a risk manager who aims at robust decisions. In committees, members evaluate alternative policy options, and face different sources of uncertainty. They individually express their views on what constitutes the best policy response given circumstances, and vote on the policy options before taking the decision. Blinder (2004) characterizes monetary policy setting by committees as a "quiet revolution" in central banking. Involving a committee in monetary policy decisions reduces the influence of a single policy-maker on the decision, but strengthens the democratic process.

Heterogeneity in a monetary policy committee is often related to different preferences and views of its members and to differences in skills, backgrounds and membership status (see section 4 for empirical tests of heterogeneity). Blinder (1998) observes that members in a committee have different preferences and need to compromise positions. For that reason, he suggests that the "central tendency" in a committee is by far more inertial (i.e. less variable) than that of a single policy-maker. A survey by the Bank for International Settlements (2009) finds that interactions in monetary policy committees are shaped by internal disagreements among policy-makers on the economic outlook and the best policy response. Several authors emphasise the beneficial effects of diverse views in monetary policy committees (see Blinder et al. 2008). Federal Reserve chairman Bernanke (2007) suggests that: "Diversity of views drives the Committee to adopt an eclectic approach and thus serves to limit the risk that a single viewpoint or analytical framework might become unduly dominant." 
Collective and individual factors may influence committee decisions on monetary policy. Discussions in committees require considerable staff input. Information by staff is normally accessible by all committee members, and represents information common to all members. In committee interactions asymmetries may still arise, because members are different. For example they have different professional backgrounds, skills and interest rate preferences. Blinder (2004) mentions different abilities to process evidence presented to them in a meeting. Information asymmetries may arise whenever members have "private" information on an issue of relevance which they do not share with their peers. On account of these factors, members' preferences and understanding of the working of the monetary policy transmission mechanism can differ even though they share a common goal.

Monetary policy committees meet frequently to discuss the economic outlook and its implications for the monetary policy stance (see Table 1$)^{2}$ The standard outcome of the meeting is a monetary policy decision which is either an unchanged monetary policy stance or an adjustment of policy rates. Prior to the meeting, members of the committee gather information relevant for the policy decision. At policy meetings, members share the available information and exchange views about the economic outlook, thereby aiming at the best possible monetary policy response given circumstances. Learning among peers has several benefits (see Jung, Mongelli and Moutot 2010, p. 329). It is part of the committee interaction and makes monetary policy decisions in the presence of uncertainty more robust. Though, learning in groups is only effective provided that members are cooperative and communicate with each other. Sibert (2002) suggests that, when the same members meet regularly "groupthink" can occur and hinder the learning process. Groupthink implies that individual members have an incentive to hide their disagreement, thereby making it impossible to distinguish between individual and collective views of committee members.

\section{See Table 1.}

Most committees keep their internal deliberations secret or publish them in an (anonymous) summary form only after intense redrafting. Blinder et al. (2008) attribute differences in disclosing policymakers' views to different consensus traditions in committees. For example, Kohn (2008) suggests that

\footnotetext{
${ }^{2}$ Most central bank statutes foresee that extraordinary meetings are scheduled should circumstances demand it (e.g. when responding to a financial crisis).
} 
FOMC members prefer to emphasise consensus and downplay diversity when communicating monetary policy decisions. Issing (2005) observes that the mode of accountability is another important factor. Most monetary policy committees are collectively accountable to the public, and provide only information on the thinking of the committee as a whole. Only few committees emphasise the individual accountability of its members (Bank of England's MPC, Swedish Riksbank's Executive Board).

A march towards greater transparency in monetary policy has not changed a widely shared reluctance among policy-makers to reveal their individual preferences on policy rates. Therefore, central bank watchers often have difficulties to observe the full diversity of policy-makers' views expressed in committee deliberations. It is popular among central bank watchers to map members of a committee in a "hawk - dove" dimension and to use this information to improve predictions of future interest rate changes. By contrast, King (2010) suggests that this notion may not be an appropriate reflection of the internal decision-making process in a committee: "I am neither hawk nor dove. Everyone on the committee votes according to his or her judgement of the outlook of the economy."

Many policy-makers think that external disagreements can be counterproductive as they may create uncertainty in financial markets and thereby raise market volatility. Some fear that publication of such information could hinder a free exchange of views at the meeting. Others have incentives to avoid confrontations with the media. Career concerns or concerns regarding their personal independence sometimes also play a role. Some central banks publish (attributed) voting records with detailed information on agreement and dissent by member. Voting records contain quantitative information on the occurrence of disperse views by policy-makers in committees. The balance of votes reports dissent and agreement on the interest rate decision by members. Such voting records give the public a sense on diversity in the committee after each meeting. Examples of central banks that publish attributed voting records are the Federal Reserve, the Bank of England, and the Swedish Riksbank.

\section{WHAT CAN BE LEARNT FROM COMMITTEES' VOTING RECORDS?}

Statistics on dissenting are not unbiased indicators of policy preferences (McCracken 2010 and Havrilesky and Gildea 1991). In general, voting records tend to understate differences in views among 
members expressed at the meeting. For example, the Fed's "bias statement" gives policy-makers a possibility to signal dissent in a non-attributed manner. Concessions to members when drafting the bias statement reduce members' incentive to dissent. Chappell, McGregor, and Vermilyea (2007) find evidence for this behavior during the period 1987 to 1992, but not for the period 1993 to 1999. Though, as illustrated by Figure 1, central bank committees with individual accountability (MPC, Riksbank's Executive Board) may have an incentive to reveal more accurate information on member's preferences within the voting records.

In the case of the FOMC and other central banks with collective accountability, better sources on diversity can be extracted from transcripts and minutes. ${ }^{3}$ They provide more detailed information on diversity of views in the committee, but are only published with considerable delays of some years. For instance, the FOMC publishes transcripts after about 5 years, and the ECB and the Deutsche Bundesbank provide access to their documents only after up to 30 years. Moreover, theses sources leave ample scope for guesswork when mapping qualitative information into quantitative information. That is why most researchers have used (attributed) voting records for the analysis of preference heterogeneity in a monetary policy committee and only few have attempted to map information from transcripts and speeches into an index describing the "mood" of each member.

In the literature the view prevails that most voting records provide useful information on diversity in a monetary policy committee, even though they do not provide readily accessible information on policymaker's individual preferences. For example, a recent study by Horváth, Smidková and Zápal (2010) finds that voting records may contain valuable information about agreement and dissent by members and about future interest rate moves. FOMC voting records have been analyzed extensively by researchers and are regularly scrutinized by Fed watchers. In a 30 year time span (1978-2008), 200 dissents were voiced in support of tighter and 125 dissents in support of looser policy (see Chappell, Havrilesky, and McGregor 1997). Policy-makers dissented in both directions (easing and tightening bias). The intensity by which FOMC policy-makers have dissented is time-varying. Meade and Sheets (2006) observe a peak in FOMC dissenting during the late 1970s and early 1980s. Paul Volcker's

\footnotetext{
${ }^{3}$ Since the October 2007 meeting, FOMC minutes include four times a year a new section on diversity of participants' views on forecasts. The information provided is not attributed to individual members, but only shows
} 
chairmanship turned out to be an era associated with an unusual high degree of dispersion. The question how aggressive monetary policy should be tightened to bring down high inflation to more moderate levels in view of strong divergences in regional unemployment rates attracted substantial disagreement within the committee.

Meade and Sheets $(2002,2005)$ report empirical evidence in support of the "regional bias hypothesis". In a federal central banking system, policy-makers from the regional offices are more likely to cast dissenting votes for tighter than for easier monetary policy. FOMC policy-makers do take into account regional unemployment rates when deciding on interest rates, but policy-makers in the periphery find these developments more important than those at the centre. The study by Besley et al. (2008) finds that several "unobserved characteristics" such as the membership status, academic background or experience working in the Treasury are potentially relevant, but cannot explain differences in the MPC members' voting patterns. They attribute heterogeneity mainly to different responses to the output gap. Another strand of the literature (see Gerlach-Kristen 2006, and Bhattacharjee and Holly 2006, and Fuijiki 2005) suggests that in committees comprising "internal" and "external" members, "external" members more often show disagreement with the policy decision. A recent study by Berk, Bierut and Meade (2010) suggests that these differences would be mainly related to the end of their tenure. By contrast, the voting behaviour of the Riksbank's Executive Board, which comprises only "internal" members, shows that all members are active dissenters (see Ekici 2009).

The insider-outsider hypothesis suggests that members appointed from within the central bank know the monetary policy process well, and vote therefore more in synch with the chairman than outsiders. Moreover, outsiders may show more extreme reaction patterns and may be less predictable than the experienced insiders. Because members can learn, outsiders eventually adapt and, after some time, they become indistinguishable from the insiders. The presence of such patterns could constitute tenure effects within the first year(s), but empirically they may be difficult to detect, because members can change their reaction pattern also in view of other factors such as extraordinary shocks (e.g. the financial crisis, a natural disaster). In the FOMC, according to Kohn (2008), tenure effects could arise because Bank Presidents have on average longer tenures than Board members. Measuring these effects

the distribution in the committee. 
is complicated by the existence of a rotation system that limits the number of observations for all regions except the Fed New York, which has a permanent seat in the FOMC. Furthermore, the career background-effects hypothesis would seem to suggest that members with an academic background, banking background or members from the Treasury behave differently in their voting patterns. In the case of the FOMC, some authors have suggested that working for the government prior to appointment would imply a more dovish monetary policy preference (see Havrilesky and Schweitzer 1990, and Chappell, Havrilesky, McGregor 1995). However, in many cases throughout their careers members of monetary policy committees work in several areas so that a distinction along this line is obviously not very sharp. Interestingly, other empirical studies on this issue for the MPC tend to reject the career background-effects hypothesis.

Table 1 (last item) reports an aggregate activity measure as a crude proxy to measure differences in the consensus mode across committees. It relates the number of dissents to total votes. The different values of the measure are a first indication that diversity may vary across policy committees. But, this aggregate measure is a sample average and does not account for the direction of dissent. Figure 1 shows the balance of votes for three monetary policy committees (FOMC, MPC, and Riksbank's Executive Board). In the period 1998-2008, FOMC members have taken decisions in a highly consensual manner. Dissenting was infrequent, and the dispersion of Board members' and regional presidents' votes was low. ${ }^{4}$ In almost all meetings a broad majority of members or all members supported the chairman's proposal on interest rates. For comparison, monetary policy committees of other central banks - such as the Bank of England and Swedish Riksbank - have taken their monetary policy decisions in a less consensual manner as indicated by a higher number of members casting a dissent throughout the whole sample. These voting records show that typically a majority of members agreed with the policy proposal. Because a majority of members supported the policy proposal, the chairman of the committee seldom exercised a casting vote.

\section{See Figure 1.}

\footnotetext{
${ }^{4}$ Transcripts show that FOMC members on occasion expressed more diversity of views during the internal assessment. Policy-makers' published forecast ranges have widened and narrowed. They imply that views in the committee on occasion have been more diverse than indicated by the balance of votes.
} 
Split interest rate decisions are another indicator for the degree of dispersion in a committee. Episodes of split interest rates were absent for the FOMC over the past decade, whereas for other committees such episodes were rare (see Riboni and Ruge-Murcia 2010, p. 401). The following examples illustrate the point. First, the Bank of England's MPC recorded about 10 occasions when a thin 5:4 majority supported the interest rate proposal. Governor Mervyn King "famously" dissented, and was outvoted on three occasions (namely August 2005, June 2007, and again in August 2009). Second, the Executive Board of the Riksbank had a tie on four occasions (namely 5 July 2001, 1 December 2005, 3 May 2007 and 3 September 2008), and the Governor's casting vote determined the outcome.

The FOMC's voting has received by far most attention in academic research. Chappell, Havrilesky and McGregor (1997) provide evidence of significant diversity during the 1970s and the 1980s both in terms of views and preferences. A host of factors seems to have contributed to more consensual voting over past decades. The "new consensus" on US monetary policy (Goodfriend 2007) which includes developments such as increased transparency on the monetary policy process, a strong ability of the chairman to forge consensus in the committee (under chairmen Greenspan and Bernanke, see Meyer 2004, p. 40), improvements in the sharing of information among policy-makers, and the popularity of the "Taylor-rule" as a tool for policy evaluation. By contrast, the monetary policy decisions of the Bank of England's MPC, and the Riksbank's Executive Board remained less consensual and this was communicated to the public (see also Riboni and Ruge-Murcia 2011). As illustrated by Figure 1, over the past decade voting records of these central banks are indicative of a considerable higher degree of dispersion in policy-makers' votes on policy rates than for the FOMC.

\section{AN ECONOMETRIC ANALYSIS OF DIVERSITY IN COMMITTEES}

This section provides and compares econometric results from Taylor-type reaction functions for the FOMC, the MPC and the Riksbank's Executive Board. The descriptive analysis of attributed voting records in the previous section has illustrated that diversity in monetary policy committees is an important phenomenon and its intensity may differ across central banks and time. So far it has been emphasised that the sources of heterogeneity may not be directly observable from that analysis owing to the confidential nature of the policy process. Given that most monetary policy committees take their interest rate decision by majority voting, knowledge about the sources of heterogeneity may help 
outsiders (e.g. central bank watchers) to predict the outcome of policy meetings.

In order to identify possible sources for disagreement among members of a monetary policy committee, econometric tools can help to assess this question. The paper estimates (pooled) Taylor-type reaction functions and extracts information from available voting records and relevant (real-time) macroeconomic data. Differences in reaction parameters across monetary policy committees and across members may provide an indication about the sources of diversity among committee members. The study by Besley et al. (2008) was the first to conduct such an approach for the Bank of England's MPC for the sample mid-1997 to mid-2007. ${ }^{5}$ Their framework of (pooled) Taylor-rule has the clear advantage that it provides for a structural interpretation of the estimated parameters. This paper applies their approach to the MPC and extends it two other monetary policy committees the FOMC and Riksbank's Executive Board. It also provides some refinements. For example, the present paper provides a clear estimation strategy - identification of the reaction functions and testing for equality of parameters - and reports results from hypotheses testing using conventional tools (i.e. Hausman-tests, Wald-tests). Moreover, Gerlach-Kristen (2009) comments that Besley's et al. approach would suffer from a pure focus on the long-run responses of members to the inflation and the output gap. It thus would leave open the issue of different short-run responses among members. In view of data limitations, it is clearly difficult to provide sound econometric results on dynamic voting patterns. This paper addresses this point by separately estimating the empirical reaction functions with and without imposing the long-run restriction from the inertia, thereby distinguishing between the short-run and long-run responses of members to incoming information.

The approach has other known limitations. First, policy-makers do not base their decisions on the estimated rule. They refer to a much broader set of indicators when taking decisions including money and credit aggregates and exchange rates. Second, policy-makers may disagree with how a simple policy rule models the transmission mechanism. For instance, channels of monetary policy transmission other than the interest rate channel are important in a financial crisis episode. Third, policy-makers may be more averse to deflationary than to inflationary shocks so that the implicit assumption of a symmetric loss function may be violated (see Kilian and Manganelli 2007).

\footnotetext{
${ }^{5}$ In order to show that the results for the MPC are comparable with them, we provide estimates for the MPC for the sample 1998 to 2007 (see under unconstrained reaction functions).
} 


\subsection{Testing for heterogeneity in monetary policy committees}

This section uses Taylor rules with real-time data, interest rate smoothing and a known numerical value that denotes the committees understanding of its primary objective - normally price stability (see Svensson 1997 and Issing 2005). In the present analysis, this value enters directly into the calculation of the inflation gap. When estimating the reaction functions, we use the inflation gap derived from a twoyear ahead inflation forecast $\left(\pi_{t+24}\right)$ at time $t$ and the (contemporaneous) output gap. The horizon of two years ahead corresponds to the policy horizon which these central banks normally would have in mind (i.e. in the absence of longer lasting shocks such as asset-price shocks). Where inflation forecasts with shorter horizons were available, tests indicated that the regression properties deteriorated. By contrast, for the output gap for which normally high uncertainty exists in real-time, in general better results were obtained using a contemporaneous measure. Here, when one- and two-year ahead measures were used, separate tests showed that the estimated parameter for the output gap deteriorate both in terms of significance and correct sign. Moreover, for reasons of confidentiality and hence lack of data availability, it is generally not possible to feed individual forecasts of members into the reaction functions. ${ }^{6}$ For the same reason, it is not possible to attribute different forecast horizons to different members.

An aggregate Taylor rule with interest-rate smoothing explaining the final outcome of the committee's deliberation is given by: ${ }^{7}$

$i_{t}=(1-\rho)\left(\alpha+\beta\left(\pi_{t+24}-\pi^{*}\right)+\gamma y_{t}\right)+\rho i_{t-1}+v_{t}$

where $\mathrm{i}$ is the (nominal) policy rate; $\pi$ is the inflation forecast; $\pi^{*}$ is the target inflation rate; $\mathrm{y}$ is the output gap; and $t$ denotes the time operator. In this specification, the equilibrium real interest rate is given by $r^{*}=\alpha-\pi^{*}$. For central banks with a numerical inflation target it can be directly observed, whereas for other central banks only the nominal natural rate is determined.

\footnotetext{
${ }^{6}$ An exception is the US for the period 1992 to 1998 for which individual forecasts have been made available (see Romer, 2010). These data could be exploited in a follow-up study.

${ }^{7}$ The Taylor principle recommends that monetary policy moves a (nominal) key interest rate by more than onefor-one with inflation. The reaction functions in this paper satisfy the Taylor principle.
} 
The above specification of the reaction function is in line with the literature (see e.g. Besley et al. 2008). It incorporates the output gap in levels but not in differences. The output gap and the inflation gap are both stationary variables so that proper identification requires including interest rate inertia. Orphanides (2003 and 2007) includes the output gap both in levels and in differences. This is not needed here, because variables in differences have no impact on the long-term relationship. When modelling policy-makers' reactions to new incoming information, anecdotal evidence suggests that policy-makers would not take changes in the output gap in a systematic manner into account, but at most would occasionally refer to it. In fact, the literature emphasises the high uncertainty surrounding the output gap itself as a useful indicator for monetary policy decision-making.

Pooled regressions with fixed and random effects and with random coefficients are then estimated. Pooled regressions with fixed effects capture the possibility that each committee member has a different interest rate preference (i.e. be more "hawkish" or "dovish" than the mean). The fixed effects regression takes the following form:

$$
i_{n, t}=(1-\rho)\left(\alpha_{n}+\beta\left(\pi_{t+24}-\pi^{*}\right)+\gamma y_{t}\right)+\rho i_{n, t-1}+\varepsilon_{n, t}
$$

with $\mathrm{n}$ denoting individual members.

The random effects model is similar to (2) in that slope parameters $(\beta, \gamma)$ are the same for all members, but differences in policy-makers' preferences $(\alpha)$ are random (where $\alpha$ comprises the mean and $\tau$ is a random deviation by member):

$$
i_{n, t}=(1-\rho)\left(\left(\alpha+\tau_{n}\right)+\beta\left(\pi_{t+24}-\pi^{*}\right)+\gamma y_{t}\right)+\rho i_{n, t-1}+\omega_{n, t}
$$

This model is used as a benchmark for comparison with the fixed effects model when applying the Hausman test (see Table 2 and 3). In order to estimate member specific slopes (see Figures 4 to 6), a random coefficients model is specified. The random coefficients model has the following representation:

$$
i_{n, t}=(1-\rho)\left(\left(\alpha+\tau_{n}\right)+\beta_{n}\left(\pi_{t+24}-\pi^{*}\right)+\gamma_{n} y_{t}\right)+\rho i_{n, t-1}+\eta_{n, t}
$$

In the reaction functions, in principle all committee members are included, and it is possible to distinguish them individually in the pooled functions. Owing to new appointments and staggered contracts the composition of committees changes over time. Therefore, the present study uses an 
unbalanced panel to take this into account. In comparison to approaches using individual reaction functions for each member, the unbalanced panel has the advantage to estimate longer runs of observations regardless of new appointments. Data for the individual (interest rate) preferences by committee members as available from the voting records are included in the individual or pooled reaction functions. As concerns the inflation gap and the output gap, all members are thought to base their vote on the staff forecast available at the time of the decision. By means of a Hausman test for correlated random effects, it is checked whether model parameters with fixed and random effects are statistically different. A rejection of the random effects model is a first condition for systematic differences in the intercept (i.e. the preference parameter) across committee members, because in that model the distribution of individual preferences around the mean is random. Then, by means of Waldtests it can be checked whether parameters in aggregate regressions and the corresponding pooled regressions are statistically equal. If coefficients across specifications are equal, heterogeneity is either absent or may still relate to subgroups of the committees (clusters) according to other unobserved factors such as membership, backgrounds, and tenure.

A comparison of the parameters of (1) with panel regressions (2 to 4) can provide information on three sources of heterogeneity in committees. First, members may share the committee's assessment of the macroeconomic situation, but may be systematically biased regarding the policy response - i.e. be more hawkish or dovish than the mean voter in the committee (see Riboni and Ruge-Murcia 2008). Preference heterogeneity defined that way implies different intercepts $(\alpha)$. Second, policy-makers may disagree on the response to the inflation forecast or inflation gap (see Berk and Bierut 2005). This form of heterogeneity would imply different slope coefficients $(\beta)$. Third, policy-makers may have different views on how to respond to the output gap (see Gerlach-Kristen 2006). This form of heterogeneity would imply different slope coefficients $(\gamma)$. Furthermore, if individual policy-makers are less inertial than the committee when taking interest rate decisions (see Blinder, 1998), this would imply differences in the coefficient $\rho$.

Heterogeneity in a monetary policy committee may be also attributable to a combination of these factors. For instance, policy-makers may assign different weights to inflation control and output smoothing, given different interpretations of the central bank's mandate. If policy-makers have a different focus on the maintenance of price stability or if the focus changes over time, it would imply 
that they have a different ratio between inflation control and output smoothing (see Sibert 2002). The sacrifice ratio can be used to describe whether policy-makers are in a "hawk" or "dove" regime (see Owyang and Ramey 2004). Then, the ratio $\sigma$ could give a supplementary indication on policy-makers' preferences for a certain regime or chairmanship.

Furthermore, some heterogeneity that results from factors not modelled in the above function may not be captured by the intercept and slope parameter estimates. First, committee members may distance themselves from the staff forecast for inflation and output (see Kohn 2008). ${ }^{8}$ Second, other factors may affect the dynamics of committee deliberations, but the reaction function does not model them as separate sources of heterogeneity. Examples include other indicators of the monetary policy stance such as exchange rates, different modes of leadership in a monetary policy committee (Blinder and Morgan 2007) and disagreements among policy-makers on the "true" objective function of monetary policy.

\subsection{Estimating reaction functions with a real-time data base}

Why is it important to use real-time data for the present analysis? In principle, these data correspond to the data set available at the time of the policy decision. Sizeable and extended revisions of economic data are an important source of data uncertainty which get lost when using final data. Moreover, there can be substantial lags between the first release and the last release of a data set. In fact, for some economies it may take several years until the process of revising data is finished (e.g. the US). Bernanke (2010) explains that a comparison of the actual federal funds rate and the Taylor rule gives a different message when using a Taylor rule with real-time forecasts of inflation instead of final values. Orphanides (2003) shows that Taylor rule parameter estimates using real-time data can be sensitive to the vintage of data and the concept of the gap variables. Taylor (2010) emphasises that final data should be used whenever the research interest is to assess the setting of the monetary policy stance with the benefit of hindsight. ${ }^{9}$ Orphanides (2001) and Svensson (2010) prefer to use real-time data when

\footnotetext{
${ }^{8}$ The ranges in the regularly published forecasts by the policy-makers of the FOMC and the Bank of Japan illustrate this point. Unfortunately, the published forecasts are not attributed to individual members, but only provide a central tendency and the complete range.

9 Judd and Rudebusch (1998) obtain stable results for an aggregate Taylor rule applying several alternative
} 
assessing the performance of monetary policy committees given their constraints (data and model uncertainty).

The database used for the present study comprises data on published voting records and real-time data on interest rates, inflation gap and output gap. In the following we discuss the properties of the data used in the econometric analysis, and appendix 1 provides details about the sources of the data.

\section{The FOMC}

The inflation gap is the difference between the inflation forecast two-years ahead and a (notional) numerical target of $2 \%$ (as advocated by Taylor 1993). The assumed numerical value is consistent with longer-run forecasts of inflation by FOMC members conditional on appropriate monetary policy, and with past outturns (for the sample 1993 - 2008, inflation, as measured by the PCE (core) deflator, was on average 1.97 per cent). It is not to suggest that FOMC members would individually or collectively share this value for policy purposes. To date the Fed has not provided an operational definition of price stability, but a value below, but close to $2 \%$ is in line with recent clarifications by Chairman Bernanke.

The present paper uses two alternative sources for the inflation forecast in real-time. One is the FOMC's Greenbook forecasts, which are available to FOMC policy-makers in real-time. Romer and Romer (2000) find that Greenbook forecasts are superior to other sources. Greenbook data are currently only available until December 2005. A second is the Survey of Professional Forecasters (SPF) which is publicly available in real-time. How do both measures of the inflation gap track final data? A plot (see Figure 2) shows that for 1993 to 2001 both real-time measures of the inflation gap tend to overestimate its outturn, and for 2001-3 the Greenbook measure underestimates it. Prior to the deflation scare, the Fed's internal Greenbook real-time measure is closer to the outturn than the SPF measure. After the deflation scare and until the outbreak of the financial crisis, the inflation gap based on the SPF real-time measure (which is based on headline CPI inflation) is reasonably close to the outturn. While some of

specifications to the early Greenspan years 1987 to 1997 . This can be taken as evidence that the Taylor rule provides a reasonable description of US monetary policy under chairman Greenspan. When using final data for inflation and output gaps, the conventional specification of the Taylor-type reaction function may nevertheless become instable, and it could be preferable to specify a Wicksell-type rule (see Orphanides 2007). 
the deviation is attributable to different definitions, anecdotal evidence suggests that the FOMC indeed overestimated the risk of deflation during the deflation scare of 2002-3 (see US Federal Reserve, Bluebook, June 2003).

\section{See Figure 2.}

Concerning the output gap for the US, the paper uses the real-time measure from the Greenbook and a real-time measure recursively estimated from Philadelphia Fed real-time data on capacity utilisation. The Congressional Budget Office (CBO) reports an alternative measure, which depends on the estimate of the natural rate of unemployment. It therefore may have exaggerated cycles over past years, in particular during the financial crisis (see Weidner and Williams 2009). Alternatively, the (final) output gap series from the OECD can be used. It is rather smooth around turning points. Figure 2 shows that the Greenbook estimates track outturns quite well, whereas the recursive measure reacts more strongly around turning points (i.e. similar to the measure from the $\mathrm{CBO}$ ).

\section{The MPC}

Inflation forecasts are conditioned on an interest rate held constant at the latest value. This forecast is part of the information set that MPC policy-makers observe in real-time. ${ }^{10}$ While the conditioning path for interest rates is unlikely to generate the best forecast, particularly at long horizons, it is the only forecast for which longer time series are available. The use of this path also facilitates a comparison with Besley et al. (2008). When computing the inflation gap, account is taken of a change in the Bank of England's inflation target. The inflation target was initially $2.5 \%$ for the RPIX, and then changed to $2.0 \%$ in terms of the CPI (see King 2004). In its inflation projections the Bank uses the CPI as of February 2004, and before that date it provided forecasts based on the RPIX.

Figure 2 shows output and inflation gaps for the UK. A set of recursive estimates for the real-time output gap is computed based on real-time GDP forecasts conditioned on constant interest rates, and a forward-looking measure based on market expectations (with GDP forecasts two years ahead). For

\footnotetext{
10 Note the Bank of England's MPC also uses forecasts conditional on market expectations, because a constant interest rate path may be less informative when policy-makers consider changing the monetary policy stance. At MPC meetings policy-makers always evaluate information available from both inflation forecasts.
} 
comparison, (final) output gap data from the OECD's production function approach is used. The measure is similar to the Treasury's trend point measure (see HM Treasury 2010). As in other economies, there have been sizeable revisions in the output gap for the United Kingdom. Figure 2 suggests that the MPC may have systematically underestimated the output gap and overestimated the inflation gap in real time. In this respect, the Bank of England's inflation forecasts seem to closely track the inflation target at the two year policy horizon. Moreover, in 2006-7 the MPC was apparently taken by surprise when an oil and commodity price shock hit the economy and caused the inflation gap to widen.

\section{The Riksbank's Executive Board}

The (real-time) inflation gap for the CPI is the difference between the (two-year ahead) inflation forecast and the inflation target of 2\% (and similarly for outturns). Real-time CPI inflation forecasts are conditioned on the assumption used in the main scenario of the Inflation Report. Until autumn 2005, the Riksbank conditioned staff inflation forecasts on constant interest rates, then changed to a path implied by market expectations. Since 2007 it has used the Riksbank's own forecast of the future interest rate, which is not an unconditional commitment for monetary policy. These changes to the conditioning path for interest rates aimed to generate the best possible forecast, given information available at the time of the decision. A comparison of inflation forecasts from various sources (see Svensson 2010) shows that the Riksbank's forecast performance for inflation is generally good, but not better than other comparator institutions (e.g. National Institute of Economic Research). In this respect, the change in the forecast assumption has not removed uncertainty about the interest rate path finally chosen by the Board.

The Riksbank uses a number of indicators to measure resource utilisation in the economy (see Svensson 2010). One of these measures is the output gap, calculated as the percentage difference between GDP and an estimated trend. For the output gap, the Riksbank publishes a measure computed on the basis of an HP filter which is considered at Board meetings. This series is available for the full sample. The output gap according to the HP method is, however, not a summary indicator on policy-makers' views on resource utilisation. Policy-makers always monitor a set of alternative measures constructed with different tools, thereby accounting for uncertainty about the output gap. 
Figure 2 shows output and inflation gaps for Sweden. The real-time measure from the Riksbank and the outturn show a close co-movement with some deviations over past years. Like the Bank of England's MPC, in real-time the Riksbank's Executive Board somewhat underestimated the output gap (see Svensson 2010). Like most other committees, during the financial crisis the Board underestimated the output loss. These observations are robust to the inclusion of an alternative measure for the outturn from the OECD. Concerning the inflation gap, the real-time measure hovers around zero for most of the sample, and then picks up at the end of it. Like the Bank of England, the Riksbank forecasts inflation to be close to its inflation target of $2 \%$ for the CPI at the two-year (ahead) policy horizon. Forecast errors are significant around the turn of economic cycles and during recessions (see Svensson 2010).

\subsection{Reaction functions for the FOMC, the MPC and the Riksbank's Executive Board}

In general, the present econometric analysis focuses on the sample 1998 to 2008. In order to check for robustness across time and data sets, the paper reports estimates covering alternative samples, as detailed below. When estimating the reaction functions it is assumed that new information from the inflation forecast regularly becomes available at the meeting of its publication, i.e. the latest publicly available forecast is used. In practice, policy-makers meet at a higher frequency and therefore have a richer data set at their disposal including a sensitivity analysis of the effects of changed forecast assumptions for inflation and output. The Bank of England's MPC and the Riksbank's Executive Board make (and publish) their projections once each quarter, whereas the FOMC has a set of new projections for each meeting.

In dynamic panels the model estimates could suffer from autocorrelation. Orphanides (2001) makes the point that it is appropriate to use OLS estimates when real-time data are used. ${ }^{11}$ Applying a GMM technique (see Arellano and Bond 1991) could have the advantage to provide unbiased estimates of the slope coefficients in a dynamic panel, but it is not necessary here given that the sample does not suffer from a small sample bias in the time dimension. ${ }^{12}$ In the following, results of pooled regressions are

\footnotetext{
${ }^{11}$ Orphanides (2003) applies both OLS and IV estimates (with four lags of the interest rate and of both gap variables) to address a possible simultaneity bias, and concludes that the results for the US are similar.

${ }^{12}$ Note in dynamic pooled regressions, the use of a lagged endogenous may imply the possibility that regressors
} 
obtained from OLS and from Generalised Least Squares (GLS) random effects coefficient estimates (applying the Swamy-Arora estimator, for details see Baltagi 2001). Concerning the aggregate regressions (1), we check for heteroscedasticity and apply White's (1980) correction in order to compute heteroscedasticity-consistent standard errors.

\section{Unconstrained reaction functions}

In a first step, the (unconstrained) reaction functions that measure the short-term response were estimated for the three committees considered. This is similar as in Besley et al. (2008), but they compute the long-term response from these regressions, whereas this paper estimates the long-term response directly in the constrained reaction functions. Table 2 reports the estimation results mainly focussing on the sample 1998 to 2008. In order to check for robustness of the estimates other samples or subsamples are included. In the case of the FOMC an earlier sample (1993 to 2003) is used for which Greenbook data were available, whereas for the sample 1998 to 2008 real-time data were taken from the SPF and the Philadelphia Fed. For the MPC the paper also reports results for the period 1998 to 2007 and for the Riksbank's Executive Board for 1999 to 2007. Table 2 shows that pooled and aggregate regressions have a high explanatory power and parameters are significant at conventional levels. In these regressions, the policy rate reacts positively to an inflationary shock and to shocks that widen the output gap. Slope coefficients are significant and have the expected sign. Apart from one subsample (Sweden 1999 to 2007), the Hausman test favours the fixed effects model, which is a first indication of preference heterogeneity among committee members. Hence, the fixed effects model is in general the benchmark for comparing parameters with the aggregate function.

\section{See Table 2.}

A number of interesting results emerge from the estimates. First, the high value of $\rho$ suggests that a large part of the level of interest rates at time $t$ is attributable to inertia in interest rates. It is explained by the fact that at a policy meeting changes in interest rates are made by small amounts of usually 25 or

are biased, if standard OLS panel regression techniques are applied. Besley et al. (2008) provide results for the MPC with the Arellano-Bond estimator. Moreover, when applying the Arellano-Bond method (not reported here for brevity of the exposition), results turn out to be broadly similar, but the intercept converges to zero. 
50 basis points (on rare occasions 75 basis points and more). Second, for the sample 1998 to 2008, Wald-tests indicate measurable differences in the intercept $(\alpha)$ that tracks preference heterogeneity for all three committees. This is a further indication of preference heterogeneity. For the FOMC, during the sample 1993 to 2003 for which Greenbook data were used, Wald-tests are, however, indicative of no measurable differences in the intercept. In addition, for the two inflation targeting central banks differences in inertia are also observed, while this is not the case for the FOMC. Differences in the inertia coefficient between aggregate and pooled regression could be attributable to Blinder's (1988) supposition that committees are more inertial than individual policy-makers. Therefore, these findings have to be further checked, for example by using constrained reaction functions. Third, as suggested in available studies with published FOMC policy-makers' forecasts differences in both members' forecasts on future inflation and output may matter (Gavin 2003, Banternghansa and McCracken 2009). For the sample 1998 to 2008, Wald-tests indicate some measurable differences of slope coefficients between corresponding aggregate and pooled reaction functions. This confirms that within a committee policy-makers can have different views on the transmission mechanism. Though, for the FOMC measurable differences of views relate to the output gap but not to the inflation gap. By contrast, during 1998 to 2008, for the two inflation-targeting committees measurable differences of views relate to the inflation forecast or inflation gap but not the output gap. The different behaviour could be attributable to the mandate of the central banks. While the dual mandate requires US policy-makers to explain their decisions also in terms of the consequences for growth, inflation-targeting central banks focus mainly on the inflationary consequences. When interpreting these results, it should be borne in mind that differences in the slope coefficients may also be attributable to the possibility that there is timevariation (e.g. MPC's reaction to the output gap) and that some committee members may not share the staff forecast. In this respect, Meade and Thornton (2010) report substantial disagreement in the FOMC on whether the output gap in real-time was a useful indicator to provide guidance for policy decisions. Fourth, in relation to the study by Besley et al. (2008) the paper finds that results for the MPC are broadly similar, but using a real-time measure for the contemporaneous output gap instead of a forwardlooking measure improves the estimates in terms of the significance of the coefficient and ensures the correct sign. ${ }^{13}$

${ }^{13}$ Besley et al. (2008) use a 12-months ahead forecast for the output gap. Their parameter estimates for the MPC 


\section{Constrained reaction functions}

In a second step, constrained reaction functions for the three committees were estimated. It allows to test for robustness of the results and to improve the quality of the parameter estimates. Table 3 reports the results for the three monetary policy committees mainly focussing on the sample 1998 to 2008 . Again, in order to check for robustness, results for other samples are included for the FOMC and the MPC. Pooled and aggregate regressions have a high explanatory power and parameters are significant at conventional levels. The policy rate reacts positively to an inflationary shock and to shocks that widen the output gap. Slope coefficients are significant, have the expected sign and can be meaningfully interpreted. With the exception of one sample (FOMC between 1993 and 2003), the Hausman test selects the fixed effects model, thereby giving a first indication for the presence of preference heterogeneity.

\section{See Table 3}

A number of interesting results emerge from the estimates. First, the high value of $\rho$ confirms that a large part of the level of interest rates at time $t$ is attributable to inertia in interest rate. Second, using a hypothetical inflation target of $2 \%$ for the FOMC would yield (implied) estimates of the natural (real) rate of interest $\mathrm{r}^{*}$ in a range of $0.4 \%$ to $2.5 \%$ depending on the specification and sample. For comparison, Laubach and Williams (2003) provide an estimate for the natural real rate of about $3 \%$ for mid-2002, and a range of $1 \%$ to $5 \%$ for a forty-year sample. For the UK, using the current inflation target of $2 \%$ in terms of the CPI provides (implied) estimates of the natural real rate of interest $r^{*}$ in a range of $3.0 \%$ and $3.5 \%$. It is broadly in line with conventional estimates. Larsen and McKeown (2004) provide a mean estimate of the natural real rate of interest of 3.7 (with a standard deviation of 0.6, sample 1992 to 2002). Benati and Vitale (2007) estimate the natural rate to have declined from $2.5 \%$ to $1.6 \%$ as it has been influenced by demographical factors such as ageing over recent years. For Sweden, using the inflation target of $2 \%$ in terms of the CPI provides (implied) estimates of the natural (real) rate of interest $r^{*}$ in a range of $0 \%$ to $0.50 \%$. These (ex ante) estimates of the natural real rate of interest are somewhat below of what has been observed for Sweden. For comparison, Benati and Vitale 
(2007) estimate the natural real rate to be close to $2 \%$. Third, as illustrated in Figure 3, policy-maker's preference parameter distributions in all three committees may be approximated by a symmetric normal distribution around the committee mean. Fourth, for the sample 1998 to 2008, Wald-tests find no statistically significant differences in the intercept $(\alpha)$ across regressions even though the fixed effects model is generally favoured by the Hausman test. This finding suggests the absence of preference heterogeneity for the committees as a whole, but still there could be heterogeneity in subgroups of members. Fifth, for the sample 1998 to 2008, with the exception of the Riksbank, Wald-tests find no statistically significant differences of slope coefficients between corresponding aggregate and pooled reaction functions. In the case of Sweden diversity of views concerning the output gap is detected in conjunction with diversity in inertia. It suggests that members disagree on how to respond to changes in the output gap. The different responses by members in the short- and longer-term as evident could be attributable to the financial crisis which led policy-makers to express stronger concern of policy-makers for output losses.

\section{See Figure 3.}

\section{Cluster analysis}

The question of whether members of monetary policy committees vote differently because of a number of "unobserved" factors has only recently received more attention in the literature (see e.g. for the FOMC Meade and Sheets 2006, and for the MPC Gerlach-Kristen 2003 and 2009, Besley et al. 2008, and for the MPC and the Riksbank Riboni and Ruge-Murcia 2011). Factors such as membership status, members' professional backgrounds, tenure (and reappointment motives) may have a separate influence on monetary policy decisions and explain why members vote differently. Anecdotal evidence for the relevance of this behaviour is available for many monetary policy committees. The phenomenon may even matter for other types of committees which comprise members with different characteristics.

In the empirical literature, several studies for the Bank of England's MPC seem to suggest that the membership status is of special importance. The literature is not fully conclusive on whether this hypothesis is valid. According to the membership hypothesis, internal committee members would behave more hawkish than external committee members. Moreover, because of his leadership role and 
his prominent role in communications, the chairman of the committee could behave differently. The membership structure is a potentially relevant variable for the FOMC and the MPC, where for the Riksbank a distinction can only be made on the role, i.e. between internal members and the chairman. By performing a cluster analysis a distinction can be made between three principal modes of membership (internal member, external member and chairman). In the case of the Fed, members of the Board of Governors are considered to be the internal members and the Fed Bank Presidents to be the external members (members of the Board Governors are appointed by the US President, and Bank Presidents by their Reserve Bank's Board of Directors). We generate a membership variable and add it to the dataset. This analysis may generate additional information in order to better judge whether an unobserved factor may capture heterogeneity in the three committees considered.

We check clusters of the individual preference parameters $\left(\alpha_{i}\right)$ and of their slope parameters $\left(\beta_{i}, \gamma_{i}\right)$ from the above (constrained) reaction functions and plot it by membership status for each policy-maker. For each committee, the fixed effects models (2) from the constrained regressions provide estimates of individual preference parameters $\alpha_{i}$ (by members). Similarly, individual slope parameters $\beta_{i}$ and $\gamma_{i}$ can be obtained from the (constrained) random coefficients models (4). A caveat is that individual forecasts of inflation and output by members should ideally be incorporated in the above estimations, but for reasons of confidentiality they are not available so that the estimated individual slope parameters only extract information on diversity from the voting records.

\section{See Figure 4.}

Figure 4 (LHS) shows a scatterplot of the individual preference parameters $\left(\alpha_{i}\right)$ for the FOMC, the MPC and the Riksbank's Executive Board grouped according to three different modes of membership (internal member, external member, chairman). Over the past decade, membership may explain to some extent differences in preferences for the FOMC, and less so for the MPC. Estimates of the preference parameters of Fed Banks' Presidents were more disperse than those of members of the Board of Governors (even though they are both fairly symmetric around the committee mean). It should be noted though, that membership and tenure are not fully independent factors in the case of the Fed. Hence, the observed differences may in part reflect tenure effects, because, as Kohn (2008) points out, Fed Presidents can be distinguished from Board members in that they have on average a longer tenure. At the same time, they have limited voting rights because of the rotation system. Interestingly, the figure 
shows that chairman Greenspan (Bernanke) was close to, but slightly above (below) the committee mean. In the case of the MPC, the preference parameter distributions for internal and external members show a fairly similar width and are symmetric around the mean. Also here membership and tenure are not fully independent factors, because this time internal members have a longer tenure of five years, whereas external members are appointed for three years (both subject to possible reappointment). Both chairmen (George, King) were close to or above the committee mean, i.e. the preferences were rather neutral. The Riksbank's Executive Board, which only comprises of internal members, just allows for a distinction between internal members and the chairman. As in the other two committees, the preference distribution was symmetric around the mean with all three chairmen in a position rather close to the committee mean. In conclusion, the above shows, differences in views on the natural rate of interest between internal and external members were rather modest. Most chairmen in our sample assumed a position close to neutral, thereby facilitating the role of a consensus builder within the monetary policy committee.

One question, which arises in this respect, is how aggressive members will respond to changes in the inflation and the output gap. It is conceivable that members with broadly similar preferences may still differ in their views on how aggressive the committee should respond to economic shocks. The sacrifice ratio of the individual slope parameters $\left(\beta_{\mathrm{i}} / \gamma_{\mathrm{i}}\right)$ provides a measure for the individual trade-offs by members in response to incoming or forecasted inflation and output data. Some authors have used it as an alternative measure for the "hawkishness" or preferences of members (see Sibert 2002, and Owyang and Ramey 2004). Figure 4 (RHS) shows a scatterplot of the sacrifice ratio by members for the FOMC, the MPC and the Riksbank's Executive Board again grouped according to the three different modes of membership (internal member, external member, chairman). The individual slope ratios of the parameter $\beta_{\mathrm{i}}$ (not shown here) indicate that members in all three committees respect the Taylor principle $(\beta>1)$. This is what would be expected from members of a central bank committee which aims to anchor inflation expectations in line with a primary price stability objective. A sacrifice ratio exceeding unity indicates that members tend to place more emphasis on deviations in the inflation gap as opposed to those in the output gap. With one exception, the ratio $\left(\beta_{\mathrm{i}} / \gamma_{\mathrm{i}}\right)$ exceeds unity suggesting that members react more strongly to changes in the inflation gap than in the output gap.

With regard to heterogeneity, the evidence presented in Figure 4 (RHS) shows that for the FOMC 
membership (or tenure) may explain some differences in the reaction to economic shocks. It is interesting that estimates of the sacrifice ratios of Fed Banks' Presidents are by far more disperse than those of members of the Board of Governors. Chairman Greenspan took a neutral position within the FOMC, and chairman Bernanke is at the less aggressive end of the distribution. The finding of more extreme sacrifice ratios of Fed Bank Presidents may also be seen as lending support to the insideroutsider hypothesis. At first glance, for the MPC the membership variable does not seem to capture heterogeneity, because the distributions between internal and external members look very similar. A closer check reveals the opposite. When the sacrifice ratios of two members are excluded from the sample as "outliers", the distributions show that external members cluster at the lower end, i.e. they are less aggressive, whereas internal members are fairly disperse and comprise aggressive and nonaggressive members. Both chairmen (George, King) were at the less aggressive end of the distribution. For the Riksbank's Executive Board the distribution of the sacrifice ratios was fairly disperse. One chairman (Heikensten) was at the aggressive end of the distribution and one chairman in a neutral position (Ingves). Overall, the picture that emerges from the comparison of slope ratios across committees is that internal members either tend to react more aggressively to the inflationary consequences of shocks than external members (MPC) or the width of the dispersion around the mean in both directions is greater (FOMC).

We are also interested in the question whether the result by Besley et al. (2008) that the distinction between members' background into Non-Academic versus Academic and Non-Treasury versus Treasury does not help to explain heterogeneity also holds for committees other than the MPC. Figures 5 and 6 provide additional clusters for all three committees, where scatterplots for the FOMC refer only to the members of the Board of Governors (because they can be identified individually and are appointed by the US President). The cluster analysis allows exploring these characteristics: i.e. the career background hypothesis according to which working for the government prior to appointment leads to more dovish behaviour and the partisanship hypothesis according to which the government may use the appointment process to actively influence the decision-making process. We generate a "background" variable from the resumes of the members and use information from Harris et al. (2010) for the MPC. The background variable refers to the main working experience of a member prior to joining the committee and takes three modes: academia, finance and government. In addition, we 
generate a "tenure" variable from the membership history. It indicates whether, with the benefit of hindsight, members' tenure was subject to changes and takes three modes: early resignation, expiration (or at least 6 years of office), and reappointment.

Figure 5 shows the distribution of individual preference parameters $\left(\alpha_{\mathrm{i}}\right)$ and of slope parameters $\left(\beta_{\mathrm{i}}, \gamma_{\mathrm{i}}\right)$ relative to members' background variable. For the FOMC and the Executive Board of the Riksbank the pattern were not systematic. In the case of the MPC, members with a career background in the government sector were somewhat more dovish than other members, though by contrast to the partisanship hypothesis, these members reacted more aggressive to economic shocks. Overall, this suggests that the career background effect is not systematic in all three committees.

Figure 6 shows the distribution of individual preference parameters $\left(\alpha_{\mathrm{i}}\right)$ and of slope parameters $\left(\beta_{\mathrm{i}}, \gamma_{\mathrm{i}}\right)$ relative to members' tenure variable. In all three committees considered several members were reappointed or resigned before their contract expired. The results suggest that tenure, as defined above, does not explain systematic differences across committees. Strikingly, most of the dispersion is attributable to members who stayed in the office until the end of their tenure. At the same time, this analysis does not suggest for any of the three monetary policy committees that members with more dovish (hawkish) preferences or members who respond less (more) aggressive to economic shocks seem to have better chances to be reappointed (are more likely to take an early resignation).

\section{CONCLUSIONS}

Diversity across policy-makers is an important feature of voting by monetary policy committees. The paper uses voting records from three monetary policy committees, the FOMC, the MPC and the Riksbank's Executive Board together with real-time information on economic variables. Detecting diversity in monetary policy committees may be hampered by several factors that are linked to the confidential nature of the policy-making process. That is why in the present paper an indirect measurement is pursued using empirical reaction functions for three monetary policy committees over the last decade and exploiting information contained in published voting records. The usual caveats apply to this analysis. Policy-makers set interest rates in real-time and consider various aspects that cannot be captured by means of a simple rule. For example, they typically consult a broad range of 
indicators and a suite of models in their assessments of inflationary risks. The reaction functions in the present study are therefore used as benchmarks, and it is not assumed that policy-makers de facto would follow a simple rule.

Applying this framework, the paper provides empirical evidence on differences in policy-makers' preferences and views on the transmission mechanism in three monetary policy committees. Heterogeneity in policy deliberations is beneficial and is an important element of group decisionmaking. The paper tests for heterogeneity among committee members and identifies several possible sources for its occurrence. Unconstrained reaction functions that measure the short-term response show that preference heterogeneity and some diversity of views on the inflation and economic outlook was present in all three committees. During 1998 to 2008, for the FOMC measurable differences of views relate to the output gap but not to the inflation gap. For the two inflation-targeting committees measurable differences of views relate to the inflation forecast or inflation gap but not the output gap. This different behaviour could be attributable to the mandate of the central banks which includes a more explicit concern for economic growth in the case of the Fed. By contrast, constrained reaction functions that measure the long-term response find that evidence in favour of preference heterogeneity in all three committees is at best weak. Preference distributions in all three committees were fairly symmetric around the respective mean and diversity of views on the output gap was only observed in the case of Sweden when including the financial crisis episode.

A cluster analysis of the Riksbank's Executive Board, which only comprises internal members, confirms that its members have disperse preferences and views on the transmission mechanism. For the FOMC and for the MPC this analysis suggests that among several background characteristics (membership, background, tenure), membership is a potentially relevant factor that may explain some of the differences in preferences. In the case of the FOMC these differences relate both to preferences and to views on the transmission in the sense that Fed Bank President's have more disperse preferences than the members of the Board of Governors which behave fairly similar. In the case of the MPC, preference heterogeneity is present but similar for internal and external members. Though, when comparing how they react to shocks, it turns out that overall internal members react more aggressively to the inflationary consequences of shocks than external members. 


\section{APPENDIX}

\section{A.1 Data and Sources}

Table A.1 provides an overview on the sources of the data used in this paper. Voting records for the FOMC are from the Fed's website: http://www.federalreserve.gov/monetarypolicy/fomccalendars.htm. Real-time data for the Fed are available from the website of the Federal Reserve Bank of Philadelphia: http://www.philadelphiafed.org. The database includes real-time series for the output gap as reported in the Greenbook (until end-2003), inflation projections from the Greenbook, and from the Survey of Professional Forecasters (SPF). Real-time data for the Bank of England are available from spreadsheets on their website: http://www.bankofengland.co.uk. The database includes voting records, and real-time inflation projections are from the Bank's Inflation Report. Real-time data for the Swedish Riksbank are

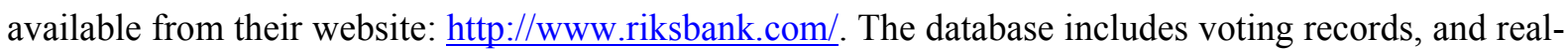
time inflation projections are from the Bank's Monetary Policy Report.

\section{TABLE A.1}

Database and sources

\begin{tabular}{|c|c|c|c|}
\hline & United States & United Kingdom & Sweden \\
\hline Voting records & $\begin{array}{l}\text { extracted from FOMC } \\
\text { minutes }\end{array}$ & $\begin{array}{l}\text { spreadsheet from the } \\
\text { website of the Bank of } \\
\text { England since June } 1997\end{array}$ & $\begin{array}{l}\text { spreadsheet from the } \\
\text { website of the Riksbank } \\
\text { since January } 1999\end{array}$ \\
\hline Inflation & $\begin{array}{l}\text { a) PCE } \\
\text { deflator } \\
\text { b) CPI } \\
\text { (website of the Federal } \\
\text { Reserve Bank of } \\
\text { Cleveland) }\end{array}$ & $\begin{array}{l}\text { CPI headline, available } \\
\text { from } 1996 .\end{array}$ & $\begin{array}{l}\text { CPI (source: Statistics } \\
\text { Sweden, and available } \\
\text { from the Riksbank's } \\
\text { website) }\end{array}$ \\
\hline Inflation forecast & $\begin{array}{l}\text { a) Greenbook data, } \\
\text { chain-weighted GDP } \\
\text { price index (until end- } \\
\text { 2003) } \\
\text { b) Survey of }\end{array}$ & $\begin{array}{l}\text { CPI headline, based on } \\
\text { constant interest rates, } \\
\text { until February } 2004 \text { the } \\
\text { RPIX was used } \\
\text { (extracted from the Bank }\end{array}$ & $\begin{array}{l}\text { CPI headline, based on } \\
\text { constant rates until } \\
\text { autumn 2005, then on } \\
\text { market rates, and since } \\
2007 \text { on the bank's }\end{array}$ \\
\hline
\end{tabular}




\begin{tabular}{|c|c|c|c|}
\hline & $\begin{array}{l}\text { Professional } \\
\text { Forecasters (CPI) } \\
\text { (source: website Fed } \\
\text { Philadelphia) }\end{array}$ & $\begin{array}{l}\text { of England's Inflation } \\
\text { Reports). }\end{array}$ & $\begin{array}{l}\text { interest rate path } \\
\text { (extracted from various } \\
\text { Monetary Policy } \\
\text { Inflation Reports of the } \\
\text { Riksbank) }\end{array}$ \\
\hline Output gap (outturn) & $\begin{array}{l}\text { a) from FRED (source: } \\
\text { Fed St. Louis database) } \\
\text { b) from the OECD } \\
\text { (OECD database) }\end{array}$ & $\begin{array}{l}\text { a) based on } \mathrm{HM} \\
\text { Treasury data (website } \\
\text { HM Treasury) } \\
\text { b) from the OECD } \\
\text { (OECD database) }\end{array}$ & $\begin{array}{l}\text { computations by the } \\
\text { Riksbank (source } \\
\text { Statistics Sweden) }\end{array}$ \\
\hline $\begin{array}{l}\text { Output gap (real- } \\
\text { time) }\end{array}$ & $\begin{array}{l}\text { a) Greenbook data } \\
\text { (until end-2003), } \\
\text { b) recursive estimate } \\
\text { from Fed releases on } \\
\text { capacity utilisation } \\
\text { (source } \\
\text { Philadelphia) }\end{array}$ & $\begin{array}{l}\text { recursive estimate, } \\
\text { calculated from the } \\
\text { Bank of England's GDP } \\
\text { real-time forecasts }\end{array}$ & $\begin{array}{l}\text { HP measure, } \\
\text { (extracted from various } \\
\text { Monetary Policy } \\
\text { Inflation Reports of the } \\
\text { Riksbank) }\end{array}$ \\
\hline Policy rate & $\begin{array}{l}\text { Fed funds target rate } \\
\text { (Fed website) }\end{array}$ & $\begin{array}{l}\text { Bank Rate (Bank of } \\
\text { England website) }\end{array}$ & $\begin{array}{l}\text { Repo rate (Swedish } \\
\text { Riksbank website) }\end{array}$ \\
\hline
\end{tabular}




\section{5 ( ) ( 5 ( $1 \&(6$}

Arellano, Manuel, and Stephen Bond. (1991) "Some Tests of Specification for Panel Data: Monte Carlo

Evidence and an Application to Employment Equations.” Review of Economic Studies, 58, 277 - 297.

Baltagi, Badi H. (2001) Econometric Analysis of Panel Data. Second Edition, West Sussex: John Wiley and Sons.

Bank for International Settlements. (2009) Issues in the Governance of Central Banks. Report of the BIS Central Bank Governance Group, Basel: BIS.

Banternghansa, Chanont, and Michael W. McCracken (2009) "Forecast Disagreement Among FOMC Members.” Fed St. Louis Working Paper No. 2009-059A.

Benati, Luca, and Giovanni Vitale. (2007) "Joint Estimation of the Natural Rate of Interest, the Natural Rate of Unemployment, Expected Inflation, and Potential Output.” ECB Working Paper No. 797.

Bénassy-Quéré, Agnes, and Edouard Turkisch. (2009) “The ECB Governing Council in an Enlarged Euro Area." Journal of Common Market Studies, 47, 25-53.

Berk, Jan M., and Beata Bierut. (2005) "Communication in Monetary Policy Committees." DNB Working Paper No. 59.

Berk, Jan M., Beata Bierut, and Ellen Meade. (2010) "The Dynamic Voting Patterns of the Bank of England's MPC." DNB Working Papers 261, De Nederlandsche Bank.

Bernanke, Ben S. (2007) "Federal Reserve Communications." Remarks at the Annual Monetary Conference of the Cato Institute, Washington, D.C., 14 November 2007.

Bernanke, Ben S. (2010) "Monetary Policy and the Housing Bubble." Remarks at the Meeting of the American Economic Association, Atlanta, 3 January 2010.

Besley, Timothy, Neil Meads, and Paolo Surico. (2008) "Insiders versus Outsiders in Monetary Policymaking.” American Economic Review: Papers and Proceedings, 98, 218-223.

Bhattacharjee, Arnab, and Sean Holly. (2006) "Taking Personalities out of Monetary Policy Decision Making? Interactions, Heterogeneity and Committee Decisions in the Bank of England's MPC." Centre for Dynamic Macroeconomic Analysis Working Paper Series No. CDMA06/12.

Blinder, Alan. (1998) Central Banking in Theory and Practice, Cambridge: MIT Press. 
Blinder, Alan. (2004) The Quiet Revolution: Central Banking Goes Modern. New Haven: Yale University Press.

Blinder, Alan. (2007) "Monetary Policy by Committee: Why and How?" European Journal of Political Economy, 23, 106-123

Blinder, Alan, Michael Ehrmann, Marcel Fratzscher, and Jakob de Haan. (2008) "Central Bank Communication and Monetary Policy: A Survey of Theory and Evidence." Journal of Economic Literature, 46, 910-945.

Blinder, Alan, and John Morgan. (2007) "Leadership in Groups: A Monetary Policy Experiment.” CEPS Working Paper No. 151.

Brainard, William. (1967) "Uncertainty and the Effectiveness of Policy." American Economic Review: Papers and Proceedings, 57, 411-425.

Chappell, Henry W. Jr., Thomas Havrilesky, and Rob R. McGregor. (1995) "Policymakers, Institutions, and Central Bank Decisions.” Journal of Economics and Business, 47, 113-136.

Chappell, Henry W. Jr., Thomas Havrilesky, and Rob R. McGregor. (1997) "Monetary Policy Preferences of Individual FOMC Members: A Content Analysis of the Memoranda of Discussion." Review of Economics and Statistics, 79, 454-460.

Chappell, Henry W. Jr., Rob R. McGregor, and Todd A. Vermilyea. (2005) Committee Decisions on Monetary Policy. Cambridge: The MIT Press.

Chappell, Henry W. Jr., Rob R. McGregor, and Todd A. Vermilyea. (2007) The Role of the Bias in Crafting Consensus: FOMC Decision Making in the Greenspan Era." International Journal of Central Banking, 3, 39-60.

Ekici, Bul. (2009) "Executive Board Voting - A Summary of the First eleven Years.” Sveriges Riksbank, Economic Commentary No. 15.

Fujiki, Hiroshi. (2005) "The Monetary Policy Committee and the Incentive Problem: A Selective Survey." Monetary and Economic Studies, 23, 37-92.

Gavin, William. (2003) "FOMC Forecast: Is All the Information in the Central Tendency?" Federal Reserve Bank of St. Louis Review, 85, 27-46.

Gerlach-Kristen, Petra. (2003) "Insiders and Outsiders at the Bank of England." Central Banking, 14, 96102. 
Gerlach-Kristen, Petra. (2006) "Monetary Policy Committees and Interest Rate Setting." European Economic Review, 50, 487-507.

Gerlach-Kristen, Petra. (2009) “Outsiders at the Bank of England's MPC.” Journal of Money, Credit and Banking, 41(6), 1099-1115.

Goodfriend, Marvin. (2007) "How the World Achieved Consensus on Monetary Policy." Journal of Economic Perspectives, 21, 47-68.

Harris, Mark, Paul Levine and Christopher Spencer. (2010) "A decade of dissent: explaining the dissent voting behavior of Bank of England MPC members.” Public Choice, 146, 413-442.

Havrilesky, Thomas and Robert Schweitzer. (1990) “A Theory of FOMC Dissent Voting with Evidence from the Time Series." in Thomas. Mayer (ed.), The Political Economy of American Monetary Policy, 197-210, Cambridge: Cambridge University Press.

Havrilesky, Thomas, and John A. Gildea. (1991) "The Policy Preferences of FOMC Members as Revealed by Dissenting Votes: A Comment.” Journal of Money, Credit and Banking, 23, 130-138

HM Treasury. (2010) "Inflation and the Output Gap in the UK." HM Treasury, Economic Working Paper No. 6 .

Horváth, Roman, Smidková, Katerina, and Jan Zápal. (2010) “Central bank’s voting records and future policy.” Czech National Bank Working Paper No. 11/2010.

Issing, Otmar. (2005) "Communication, Transparency, Accountability: Monetary Policy in the TwentyFirst Century." Federal Reserve Bank of St. Louis Review, 87, 65-83.

Judd, John P. and Glenn D. Rudebusch. (1998) “Taylor's Rule and the Fed: 1970-1997." FRBSF Economic Review, 3, 3-16.

Jung, Alexander, Francesco Paolo Mongelli, and Philippe Moutot (2010) "How are the Eurosystem's Monetary Policy Decisions Prepared? A Roadmap.” Journal of Common Market Studies, 48, 319-345.

Larsen, Jens, and Jack McKeown. (2004) "The Informational Content of Empirical Measures of Real Interest Rate and Output Gaps for the United Kingdom." Bank of England, Working Paper series No. 224. 
Laubach, Thomas, and John C. Williams. (2003) "Measuring the Natural Rate of Interest." Review of Economics and Statistics, 85, 1063-1070.

Kilian, Lutz, and Simone Manganelli. (2008) "The Central Banker as a Risk Manager: Estimating the Federal Reserve's Preferences under Greenspan.” Journal of Money, Credit and Banking, 40, 1103-1129.

King, Mervyn. (2004) “The Governor's Speech at the Annual Birmingham Forward/CBI Business Luncheon.” Bank of England Quarterly Bulletin, 44, 74-76.

King, Mervyn (2010) “The Governor's Speech at the Mansion House.” Bank of England Quarterly Bulletin, 50, 226.

Kohn, Donald L. (2008) "Expertise and Macroeconomic Policy, Comments on Insiders versus Outsiders in Monetary Policymaking by Timothy Besley, Neil Meads, and Paolo Surico.” Remarks at the Meeting of the American Economic Association, New Orleans, Louisiana, 4 January 2008.

McCracken, Michael. (2010) "Disagreement at the FOMC: The Dissenting Votes Are Just Part of the Story", Federal Reserve Bank of St. Louis The Regional Economist, October 2010, pp. 10-16.

Meade, Ellen E., and Nathan Sheets. (2002) "Regional Influences on U.S. Monetary Policy: Some Implications for Europe.” Federal Reserve Board, International Finance Discussion Paper No. 720.

Meade, Ellen E., and Nathan Sheets. (2005) "Regional Influences on FOMC Voting Patterns." Journal of Money, Credit, and Banking, 37, 661-677.

Meade, Ellen E. and Nathan Sheets. (2006) "Documenting FOMC Voting Patterns." In The European Integration Process: A Changing Environment for National Central Banks, edited by OENB, Vienna.

Meade, Ellen E. and Daniel L. Thornton. (2010) "The Phillips curve and US monetary policy: what the FOMC transcripts tell us." Working Papers 2010-017, Federal Reserve Bank of St. Louis.

Meyer, Lawrence. (2004) A Term at the Fed - an Insider's View. New York: Harper and Row.

Moutot, Philippe, Alexander Jung, and Francesco Paolo Mongelli. (2008) "The Workings of the Eurosystem, Monetary Policy Preparations and Decision-making - Selected Issues.” ECB Occasional Paper No. 79.

Orphanides, Athanasios. (2001) "Monetary Policy Rules based on Real-Time Data.” American Economic Review, 91, 964-985. 
Orphanides, Athanasios. (2003) "Historical Monetary Policy Analysis and the Taylor Rule." Journal of Monetary Economics, 50, 983-1022.

Orphanides, Athanasios. (2007) "Taylor Rules.” Federal Reserve Board, Finance and Economics Discussion Series No. 2007-18.

Owyang, Michael T., and Garey Ramey. (2004) "Regime Switching and Monetary Policy Measurement.” Journal of Monetary Economics, 51, 1577-1597.

Riboni, Alessandro, and Ruge-Murcia Francisco. (2008) "Preference Heterogeneity in Monetary Policy Committees." International Journal of Central Banking, 4, 213-233.

Riboni, Alessandro, and Ruge-Murcia, Francisco. (2010) “Dissent in Monetary Policy Decisions.” Rimini Centre for Economic Analysis, Working Paper No. WP 11-27.

Riboni, Alessandro, and Ruge-Murcia, Francisco. (2011) "Monetary Policy by Committee: Consensus, Chairman Dominance, or Simple Majority?” Quarterly Journal of Economics, 125, 363-416.

Romer, Christina D., and David H. Romer. (2000) "Federal Reserve Information and the Behavior of Interest Rates.” American Economic Review, 90, 429-457.

Romer, David H. (2010) "A New Data Set on Monetary Policy: The Economic Forecasts of Individual Members of the FOMC." Journal of Money, Credit, and Banking, 42, 951-957.

Sibert, Anne. (2002) "Monetary Policy with Uncertain Central Bank Preferences.” European Economic Review, 46, 1093-1109.

Svensson, Lars. (1997) "Inflation Forecast Targeting: Implementing and Monitoring Inflation Targets." European Economic Review, 41, 1111-1146.

Svensson, Lars. (2010) “Assessment of Monetary Policy in Sweden in 2009.” Remarks at the Centre for Business and Policy Studies, Stockholm, 18 March 2010.

Taylor, John B. (1993) "Discretion versus Policy Rules in Practice." Carnegie-Rochester Conference Series on Public Policy, 39, 195 - 214.

Taylor, John B. (2010) “The Fed and the Crisis: A Reply to Ben Bernanke.” Wall Street Journal, January 11.

Weidner, Justin, and John C. Williams. (2009) "How Big is the Output Gap?" FRBSF Economic Letter 
No. 2009-19.

White, Halbert (1980) "A heteroscedasticity-consistent covariance matrix estimator and a direct test for heteroscedasticity." Econometrica, 48 (4), 817-838. 


\section{FIGURES AND TABLES}

FIGURE 1: Voting and dissenting in Monetary Policy Committees (1998 - 2008)

The Federal Reserve's FOMC

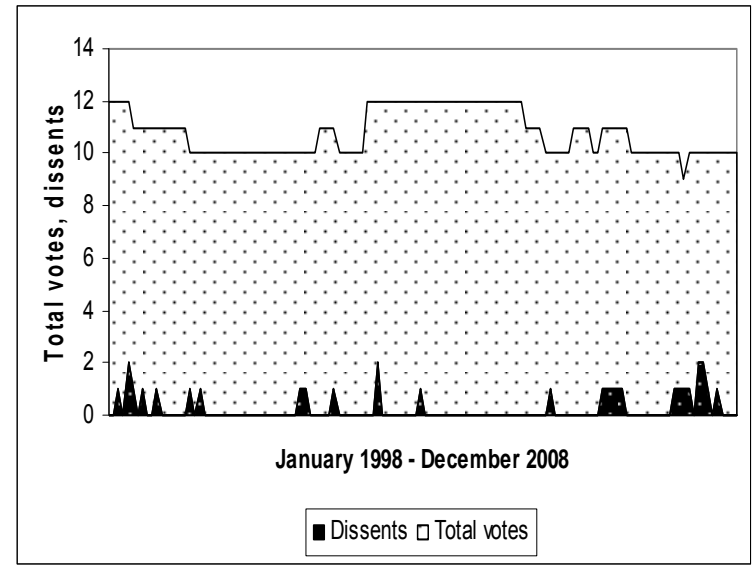

The Bank of England's MPC

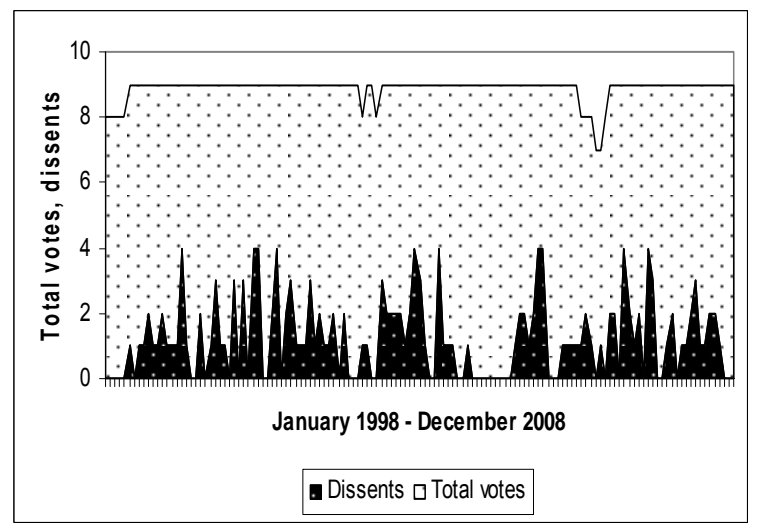

The Riksbank’s Executive Board

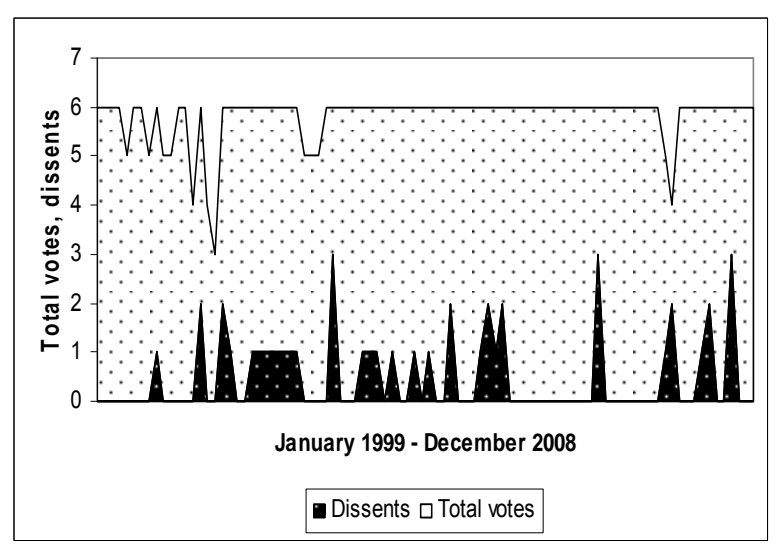

Sources: US Federal Reserve, Bank of England, Swedish Riksbank (see description in the appendix). 
FIGURE 2: Output gap and inflation gap for the US, the UK and Sweden

Output gap


\begin{tabular}{|l|}
$-1-$ - Riksbank (real-time measure based on HP) \\
- Outturn (Riksbank HP measure) \\
- Outturn (OECD measure)
\end{tabular}
Inflation gap
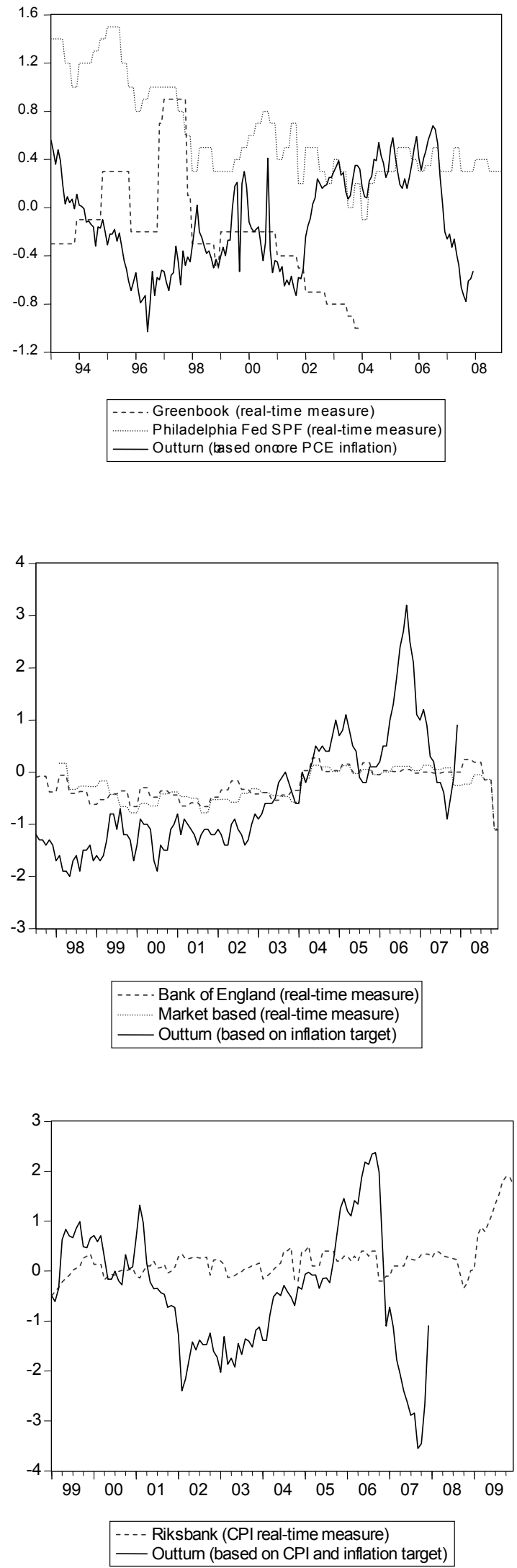

Notes: Upper panel: United States, Mid panel: United Kingdom, Lower panel: Sweden.

Sources: US Federal Reserve, Bank of England, Swedish Riksbank (see description in the appendix). 
FIGURE 3: Distributions of the preference parameter in three monetary policy committees

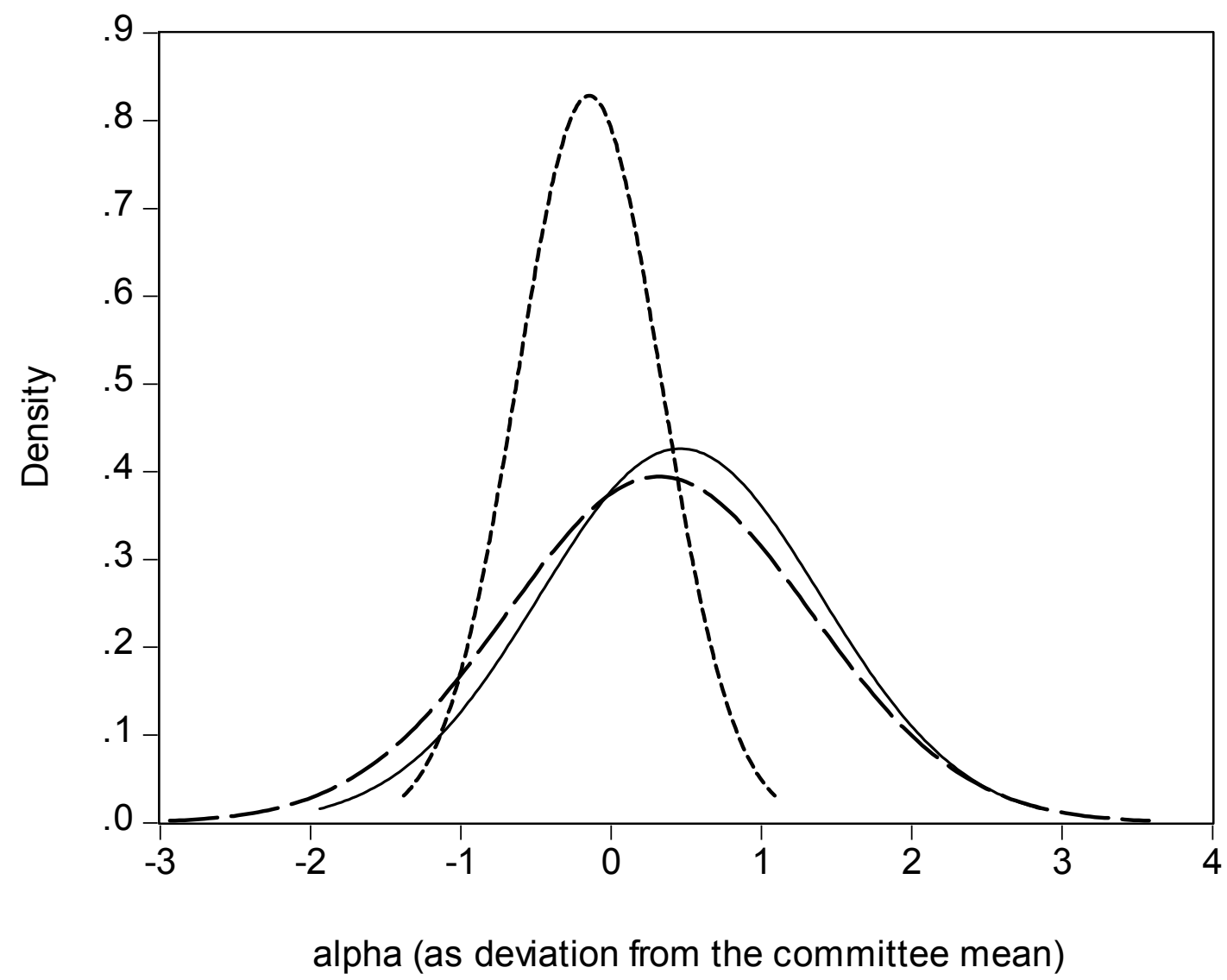

Notes: Estimates from constrained fixed effects model. Members with short observation periods have been excluded from the panel. 
FIGURE 4: Membership clusters of committee members in the three monetary policy committees

Heterogeneity of the intercept
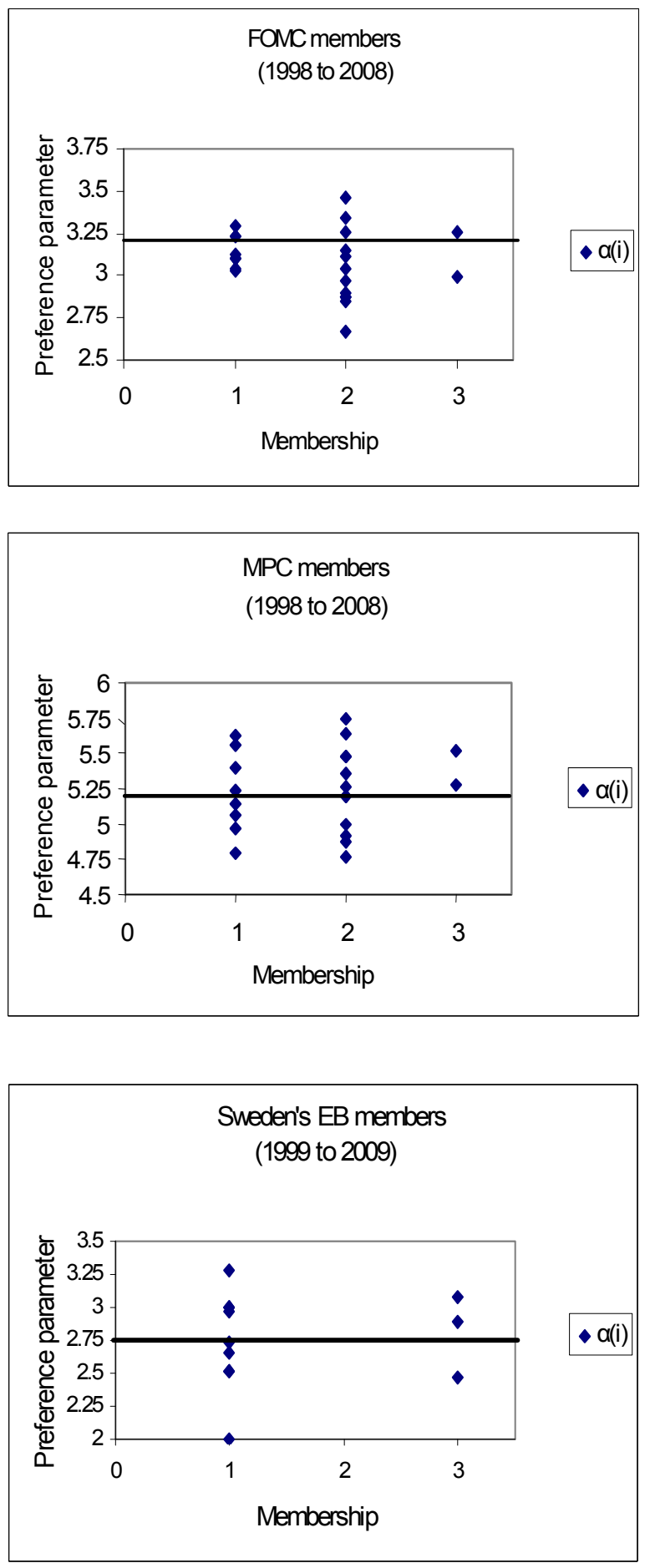

Heterogeneity of the slope parameters
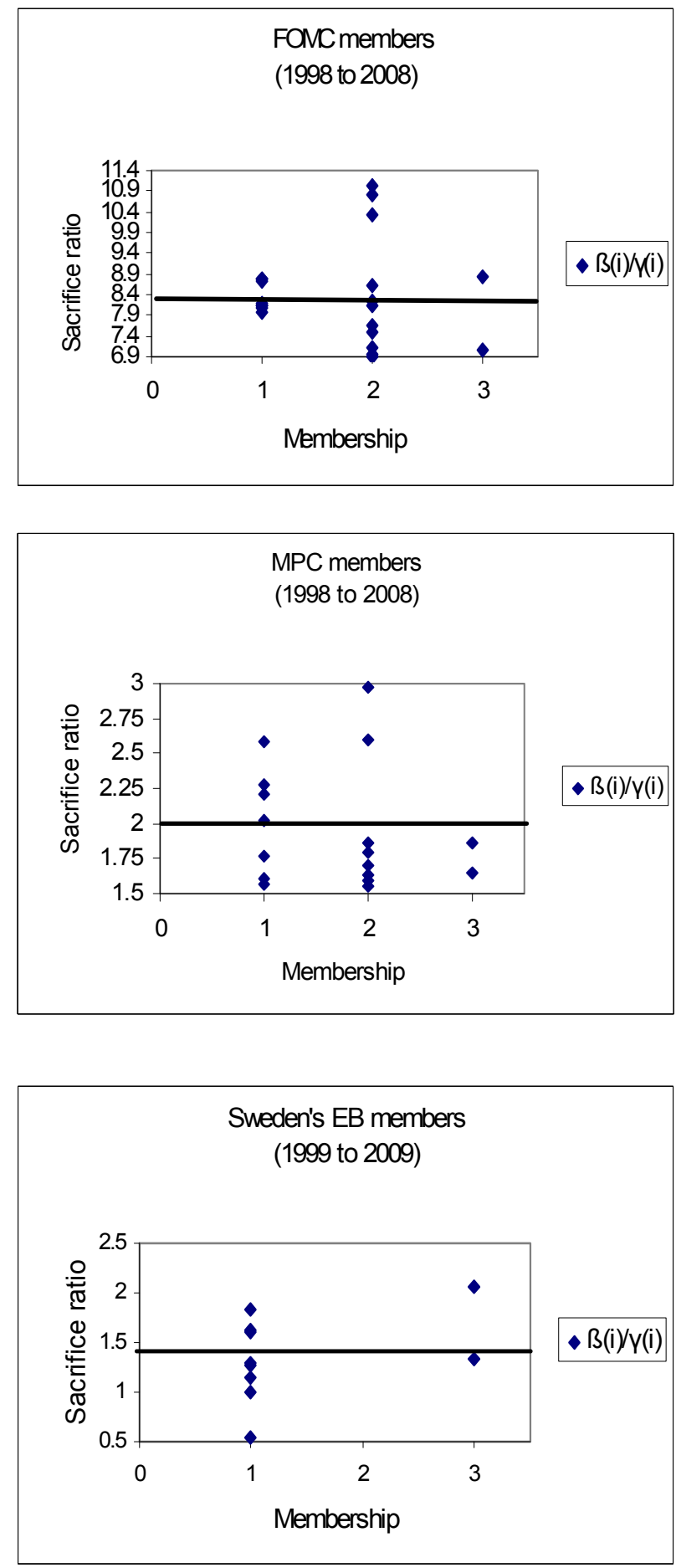

Notes: LHS: Estimates from constrained fixed effects model. RHS: Estimates from constrained random coefficients model. Membership takes different values. 1: internal member (FOMC: member of the Board of Governors), 2: external member (FOMC: President of a Federal Reserve Bank), and 3: chairman. A solid, horizontal line shows the average preference parameter for these members. Members with short observation periods have been excluded from the panel. 
FIGURE 5: Background clusters of committee members in the three monetary policy committees

Heterogeneity of the intercept
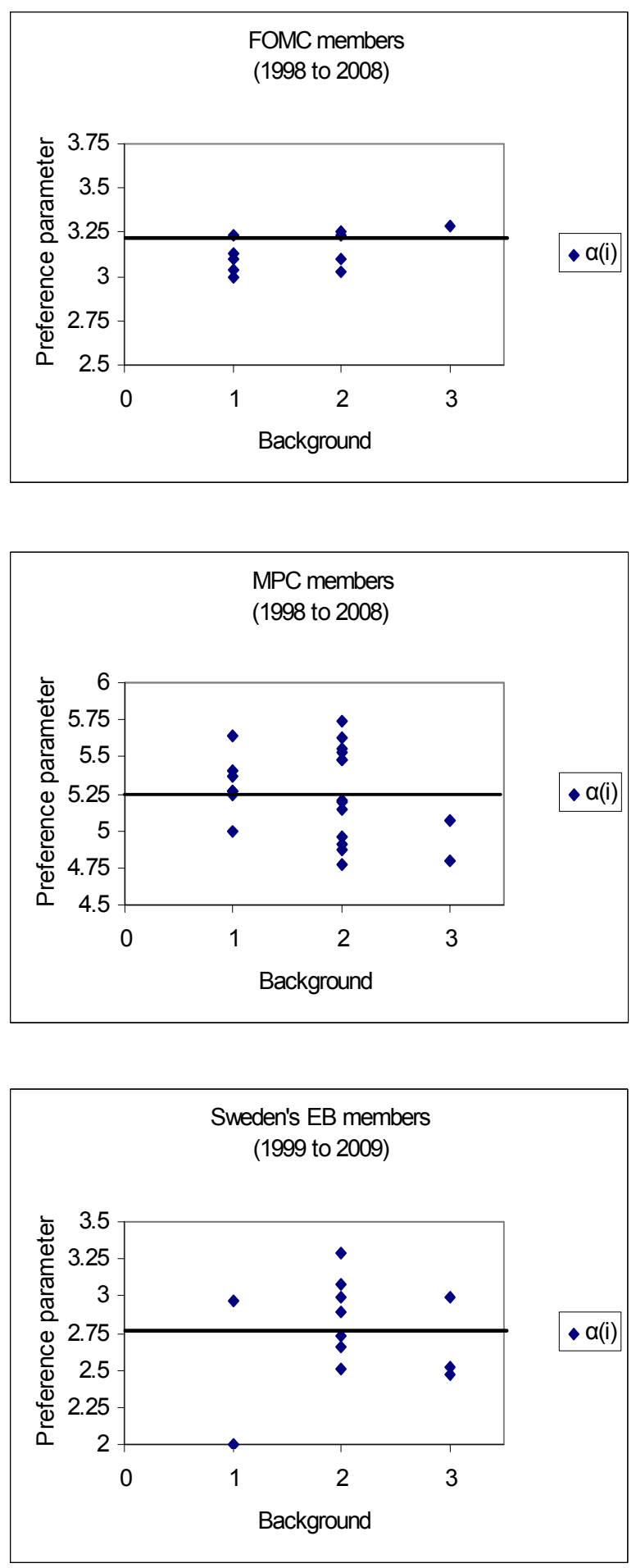

Heterogeneity of the slope parameters
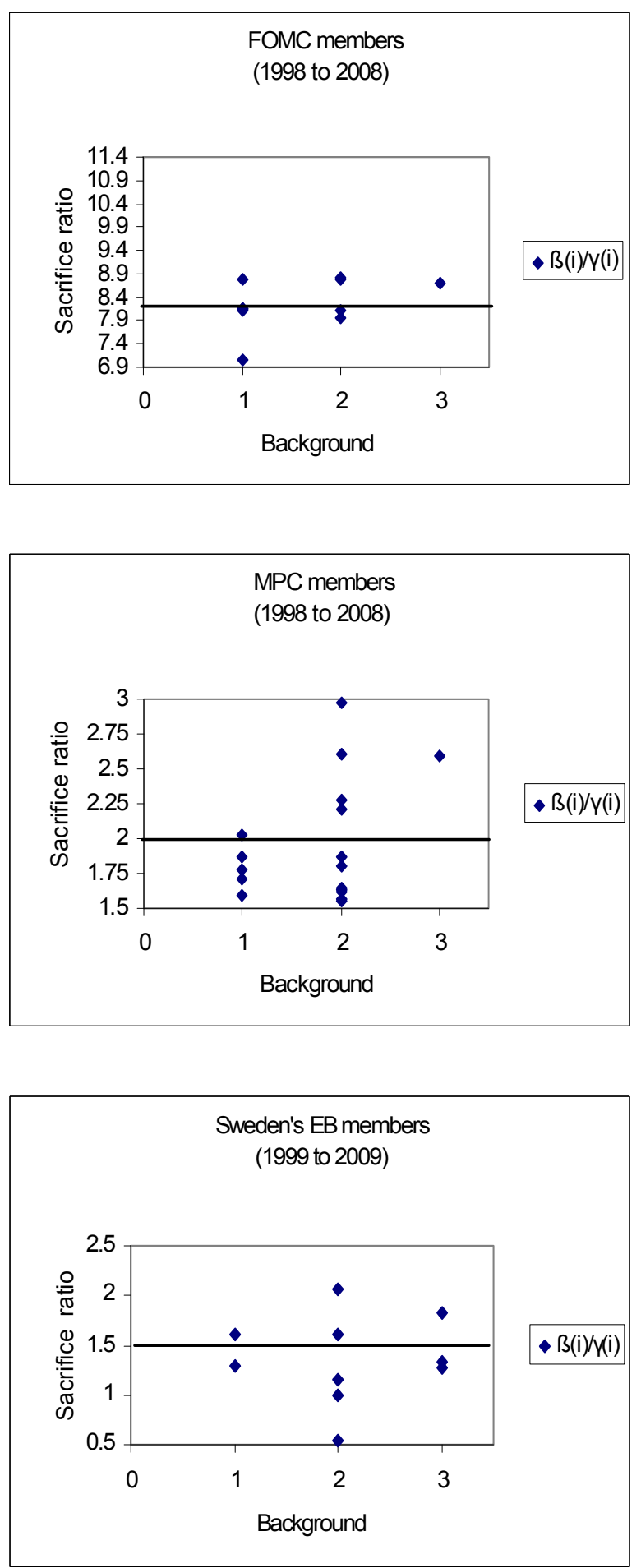

Notes: LHS: Estimates from constrained fixed effects model. RHS: Estimates from constrained random coefficients model. Background takes different values. 1: Academia, 2: Finance, and 3: Government. For the FOMC the above results apply to the members of the Board of Governors. A solid, horizontal line shows the average preference parameter for these members. Members with short observation periods have been excluded from the panel. 
FIGURE 6: Tenure clusters of committee members in the three monetary policy committees

Heterogeneity of the intercept
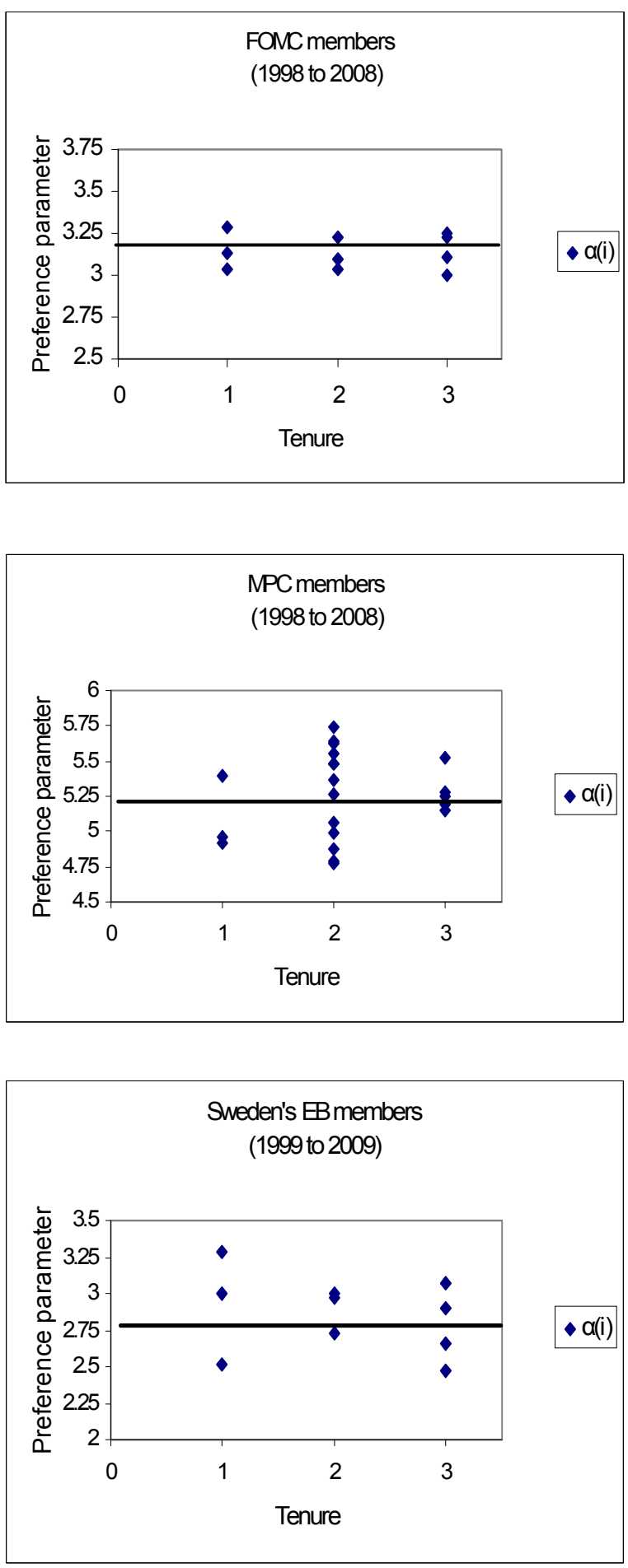

Heterogeneity of the slope parameters
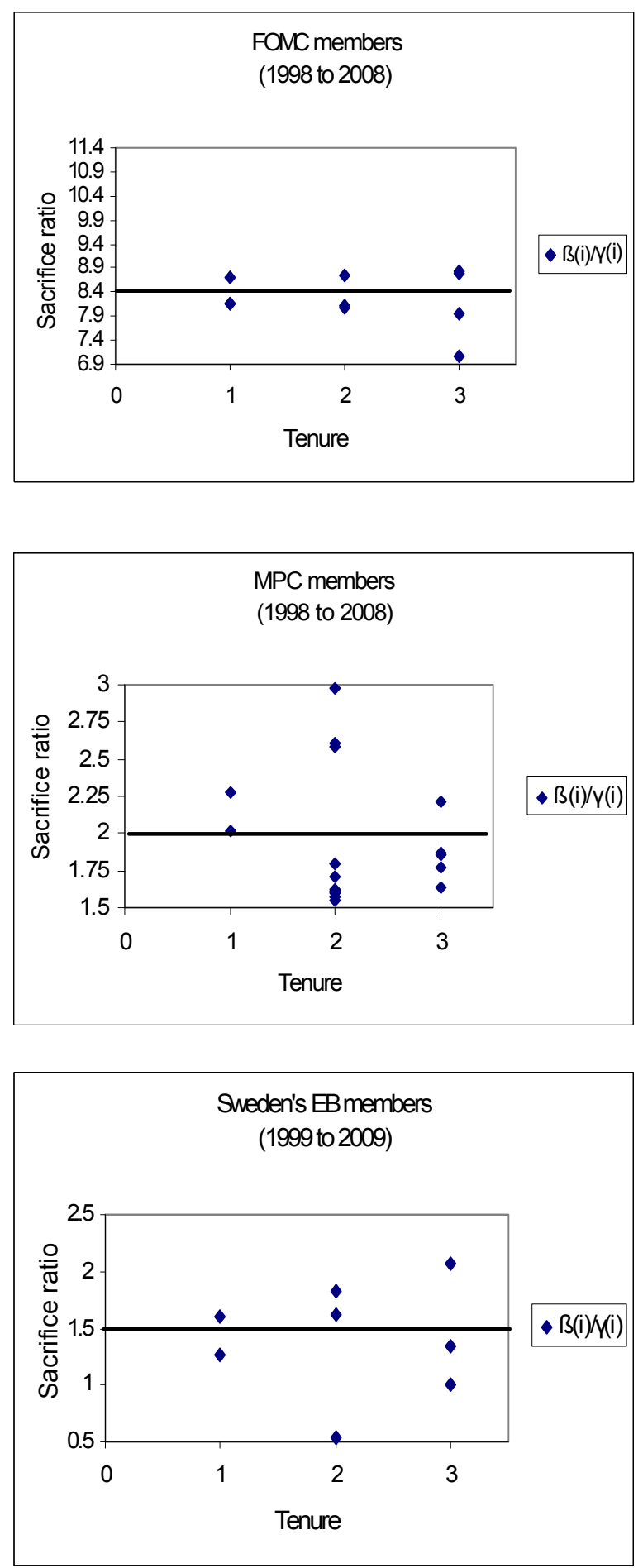

Notes: LHS: Estimates from constrained fixed effects model. RHS: Estimates from constrained random coefficients model. Tenure takes different values: 1: Early resignation, 2: Expiration, and 3: Reappointment. For the FOMC the above results apply to the members of the Board of Governors. A solid, horizontal line shows the average preference parameter for these members. Members with short observation periods have been excluded from the panel. 
TABLE 1: Key Voting Characteristics of three Monetary Policy Committees (1999 - 2008)

\begin{tabular}{|c|c|c|c|}
\hline & $\begin{array}{c}\text { Federal Reserve } \\
\text { System }\end{array}$ & Bank of England & Swedish Riksbank \\
\hline $\begin{array}{l}\text { (1) Number of voting } \\
\text { members }\end{array}$ & 12 & 9 & 6 \\
\hline Internal members $^{\mathrm{a}}$ & 7 & 5 & 6 \\
\hline External members & 5 & 4 & 0 \\
\hline \multicolumn{4}{|l|}{$\begin{array}{l}\text { (2) Number of meetings } \\
\text { on monetary policy }\end{array}$} \\
\hline $\begin{array}{l}\text { Regular committee } \\
\text { meetings per yearc }\end{array}$ & 8 & 12 & 6 \\
\hline 5 years: $1999-2003$ & 45 & 96 & 54 \\
\hline 10 years: $1999-2008$ & 94 & 157 & 90 \\
\hline \multicolumn{4}{|c|}{$\begin{array}{l}\text { (3) Number of meetings } \\
\text { with changes in policy } \\
\text { rates }\end{array}$} \\
\hline 5 years: $1999-2003$ & 19 & 15 & 14 \\
\hline 10 years: $1999-2008$ & 45 & 27 & 33 \\
\hline \multicolumn{4}{|c|}{$\begin{array}{l}\text { (4) Frequency of policy } \\
\text { rate changes in relation to } \\
\text { number of meetings }\end{array}$} \\
\hline 5 years: $1999-2003$ & 0.42 & 0.16 & 0.26 \\
\hline 10 years: $1999-2008$ & 0.48 & 0.17 & 0.37 \\
\hline \multicolumn{4}{|c|}{$\begin{array}{l}\text { (5) Frequency of dissents } \\
\text { in relation to total votes }\end{array}$} \\
\hline 5 years: $1999-2003$ & 0.01 & 0.16 & 0.09 \\
\hline 10 years: $1999-2008$ & 0.02 & 0.14 & 0.08 \\
\hline
\end{tabular}

Notes: Most interest rate changes in the sample were by 25 or 50 basis points.

a) Owing to unfilled positions, the number of internal members in the FOMC was sometimes smaller.

b) Including unscheduled meetings such as conference calls. c) In the sample, the Executive Board

of the Riksbank reduced the number of ordinary meetings at which policy rates can be changed. 
TABLE 2: Unconstrained reaction functions for three Monetary Policy Committees

\begin{tabular}{|c|c|c|c|c|c|c|c|c|c|}
\hline \multicolumn{10}{|l|}{ FOMC } \\
\hline & $\begin{array}{l}\text { Coefficients } \\
\text { Equation }\end{array}$ & $\alpha(1-\rho)$ & $\beta(1-\rho)$ & $\gamma(1-\rho)$ & $\rho$ & Prob. & $\mathbf{R}^{2}$ & Obs. & $\begin{array}{l}\text { Pooled } \\
\text { obs. }\end{array}$ \\
\hline \multirow[t]{3}{*}{$\begin{array}{c}1993 \text { to } \\
2003\end{array}$} & Aggregate & $\begin{array}{l}0.287 \\
(0.027)\end{array}$ & $\begin{array}{l}0.175 \\
(0.015)\end{array}$ & $\begin{array}{l}0.043 \\
(0.005)\end{array}$ & $\begin{array}{l}0.936 \\
(0.006)\end{array}$ & & 0.99 & 132 & - \\
\hline & $\begin{array}{l}\text { Fixed } \\
\text { Effects }\end{array}$ & $\begin{array}{l}0.279 \\
(0.029)\end{array}$ & $\begin{array}{l}0.150 \\
(0.016)\end{array}$ & $\begin{array}{l}0.051 \\
(0.005)\end{array}$ & $\begin{array}{l}0.938 \\
(0.007)\end{array}$ & & 0.99 & 132 & 1371 \\
\hline & Random Effects & $\begin{array}{l}0.278 \\
(0.030)\end{array}$ & $\begin{array}{l}0.159 \\
(0.016)\end{array}$ & $\begin{array}{l}0.046 \\
(0.005)\end{array}$ & $\begin{array}{l}0.940 \\
(0.006)\end{array}$ & $<0.01$ & 0.99 & 132 & 1371 \\
\hline \multirow[t]{3}{*}{$\begin{array}{c}1998 \text { to } \\
2008\end{array}$} & Aggregate & $\begin{array}{l}0.129 * \\
(0.011)\end{array}$ & $\begin{array}{l}0.255 \\
(0.023)\end{array}$ & $\begin{array}{l}0.031 * \\
(0.001)\end{array}$ & $\begin{array}{l}0.945 \\
(0.003)\end{array}$ & & 0.99 & 132 & - \\
\hline & $\begin{array}{l}\text { Fixed } \\
\text { Effects }\end{array}$ & $\begin{array}{l}0.202^{*} \\
(0.022)\end{array}$ & $\begin{array}{l}0.198 \\
(0.041)\end{array}$ & $\begin{array}{l}0.038^{*} \\
(0.002)\end{array}$ & $\begin{array}{l}0.938 \\
(0.006)\end{array}$ & & 0.99 & 132 & 1373 \\
\hline & Random Effects & $\begin{array}{l}0.180 \\
(0.025)\end{array}$ & $\begin{array}{l}0.205 \\
(0.041)\end{array}$ & $\begin{array}{l}0.036 \\
(0.002)\end{array}$ & $\begin{array}{l}0.940 \\
(0.005)\end{array}$ & $<0.01$ & 0.99 & 132 & 1373 \\
\hline \multicolumn{10}{|l|}{ MPC } \\
\hline \multirow[t]{3}{*}{$\begin{array}{c}1998 \text { to } \\
2007\end{array}$} & Aggregate & $\begin{array}{l}0.164 * \\
(0.012)\end{array}$ & $\begin{array}{l}0.116^{*} \\
(0.011)\end{array}$ & $\begin{array}{l}0.061^{*} \\
(0.004)\end{array}$ & $\begin{array}{l}0.971 * \\
(0.003)\end{array}$ & & 0.98 & 120 & - \\
\hline & $\begin{array}{l}\text { Fixed } \\
\text { Effects }\end{array}$ & $\begin{array}{l}0.337 * \\
(0.031)\end{array}$ & $\begin{array}{l}0.256^{*} \\
(0.022)\end{array}$ & $\begin{array}{l}0.122 * \\
(0.009)\end{array}$ & $\begin{array}{l}0.933 * \\
(0.006)\end{array}$ & & 0.98 & 120 & 1049 \\
\hline & Random Effects & $\begin{array}{l}0.319 \\
(0.029)\end{array}$ & $\begin{array}{l}0.236 \\
(0.018)\end{array}$ & $\begin{array}{l}0.121 \\
(0.008)\end{array}$ & $\begin{array}{l}0.936 \\
(0.005)\end{array}$ & $<0.01$ & 0.98 & 120 & 1049 \\
\hline \multirow[t]{3}{*}{$\begin{array}{c}1998 \text { to } \\
2008\end{array}$} & Aggregate & $\begin{array}{l}0.129 * \\
(0.016)\end{array}$ & $\begin{array}{l}0.162 * \\
(0.012)\end{array}$ & $\begin{array}{l}0.124 \\
(0.004)\end{array}$ & $\begin{array}{l}0.971 * \\
(0.003)\end{array}$ & & 0.97 & 132 & - \\
\hline & $\begin{array}{l}\text { Fixed } \\
\text { Effects }\end{array}$ & $\begin{array}{l}0.363^{*} \\
(0.038) \\
\end{array}$ & $\begin{array}{l}0.302 * \\
(0.025) \\
\end{array}$ & $\begin{array}{l}0.119 \\
(0.008)\end{array}$ & $\begin{array}{l}0.938^{*} \\
(0.007) \\
\end{array}$ & & 0.96 & 132 & 1156 \\
\hline & Random Effects & $\begin{array}{l}0.137 \\
(0.030)\end{array}$ & $\begin{array}{l}0.167 \\
(0.023)\end{array}$ & $\begin{array}{l}0.120 \\
(0.008)\end{array}$ & $\begin{array}{l}0.977 \\
(0.006) \\
\end{array}$ & $<0.01$ & 0.97 & 132 & 1156 \\
\hline \multicolumn{10}{|c|}{ Riksbank's Executive Board } \\
\hline \multirow[t]{3}{*}{$\begin{array}{c}1999 \text { to } \\
2007\end{array}$} & Aggregate & $\begin{array}{l}0.074 * \\
(0.017) \\
\end{array}$ & $\begin{array}{l}0.111^{*} \\
(0.021) \\
\end{array}$ & $\begin{array}{l}0.086 \\
(0.007) \\
\end{array}$ & $\begin{array}{l}0.970 * \\
(0.005) \\
\end{array}$ & & 0.97 & 107 & - \\
\hline & $\begin{array}{l}\text { Fixed } \\
\text { Effects }\end{array}$ & $\begin{array}{l}0.183 \\
(0.068) \\
\end{array}$ & $\begin{array}{l}0.312 \\
(0.082)\end{array}$ & $\begin{array}{l}0.072 \\
(0.024) \\
\end{array}$ & $\begin{array}{l}0.931 \\
(0.020)\end{array}$ & & 0.94 & 107 & 226 \\
\hline & Random Effects & $\begin{array}{l}0.177 * \\
(0.064) \\
\end{array}$ & $\begin{array}{l}0.328^{*} \\
(0.080) \\
\end{array}$ & $\begin{array}{l}0.078 \\
(0.023) \\
\end{array}$ & $\begin{array}{l}0.932 * \\
(0.019)\end{array}$ & 0.68 & 0.94 & 107 & 226 \\
\hline \multirow[t]{3}{*}{$\begin{array}{c}1999 \text { to } \\
2008\end{array}$} & Aggregate & $\begin{array}{l}0.108^{*} \\
(0.024) \\
\end{array}$ & $\begin{array}{l}0.190 * \\
(0.029) \\
\end{array}$ & $\begin{array}{l}0.123 \\
(0.010) \\
\end{array}$ & $\begin{array}{l}0.950^{*} \\
(0.007)\end{array}$ & & 0.94 & 119 & - \\
\hline & $\begin{array}{l}\text { Fixed } \\
\text { Effects }\end{array}$ & $\begin{array}{l}0.309 * \\
(0.101)\end{array}$ & $\begin{array}{l}0.355^{*} \\
(0.115)\end{array}$ & $\begin{array}{l}0.160 \\
(0.036)\end{array}$ & $\begin{array}{l}0.877 * \\
(0.029)\end{array}$ & & 0.84 & 119 & 244 \\
\hline & Random Effects & $\begin{array}{l}0.323 \\
(0.103)\end{array}$ & $\begin{array}{l}0.401 \\
(0.117)\end{array}$ & $\begin{array}{l}0.153 \\
(0.037)\end{array}$ & $\begin{array}{l}0.868 \\
(0.029)\end{array}$ & 0.02 & 0.84 & 119 & 244 \\
\hline
\end{tabular}

Notes: Standard errors in brackets. Prob.: Hausman specification test selects the random effects model, if the probability exceeds $5 \%$ - otherwise the fixed effects model is sufficient. *) Wald tests reject that parameters are equal at $5 \%$ level. 
TABLE 3: Constrained reaction functions for three Monetary Policy Committees

\begin{tabular}{|c|c|c|c|c|c|c|c|c|c|}
\hline \multicolumn{10}{|l|}{ FOMC } \\
\hline \multirow{4}{*}{$\begin{array}{c}\text { Sample } \\
1993 \text { to } \\
2003\end{array}$} & $\begin{array}{l}\text { Coefficients } \\
\text { Equation }\end{array}$ & $\boldsymbol{\alpha}$ & $\boldsymbol{\beta}$ & $\gamma$ & $\rho$ & Prob. & $\mathbf{R}^{2}$ & Obs. & $\begin{array}{l}\text { Pooled } \\
\text { obs. }\end{array}$ \\
\hline & Aggregate & $\begin{array}{l}4.449 \\
(0.304)\end{array}$ & $\begin{array}{l}2.706 \\
(0.613)\end{array}$ & $\begin{array}{l}0.715 \\
(0.143)\end{array}$ & $\begin{array}{l}0.939 \\
(0.018)\end{array}$ & & 0.99 & 131 & - \\
\hline & $\begin{array}{l}\text { Fixed } \\
\text { Effects }\end{array}$ & $\begin{array}{l}4.551 \\
(0.116)\end{array}$ & $\begin{array}{l}2.271 \\
(0.267)\end{array}$ & $\begin{array}{l}0.877 \\
(0.066)\end{array}$ & $\begin{array}{l}0.943 \\
(0.006)\end{array}$ & & 0.94 & 130 & 1394 \\
\hline & $\begin{array}{l}\text { Random } \\
\text { Effects }\end{array}$ & $\begin{array}{l}4.553 \\
(0.108)\end{array}$ & $\begin{array}{l}2.959 \\
(0.292)\end{array}$ & $\begin{array}{l}0.701 \\
(0.060)\end{array}$ & $\begin{array}{l}0.943 \\
(0.006)\end{array}$ & 0.946 & 0.94 & 130 & 1262 \\
\hline \multirow[t]{3}{*}{$\begin{array}{c}1998 \text { to } \\
2008\end{array}$} & Aggregate & $\begin{array}{l}2.374 \\
(0.789)\end{array}$ & $\begin{array}{l}4.599 \\
(1.611)\end{array}$ & $\begin{array}{l}0.569 \\
(0.116)\end{array}$ & $\begin{array}{l}0.946 \\
(0.018)\end{array}$ & & 0.99 & 132 & - \\
\hline & $\begin{array}{l}\text { Fixed } \\
\text { Effects }\end{array}$ & $\begin{array}{l}3.055 \\
(0.034)\end{array}$ & $\begin{array}{l}2.984 \\
(0.523)\end{array}$ & $\begin{array}{l}0.592 \\
(0.034)\end{array}$ & $\begin{array}{l}0.933 \\
(0.005)\end{array}$ & & 0.97 & 132 & 1381 \\
\hline & $\begin{array}{l}\text { Random } \\
\text { Effects }\end{array}$ & $\begin{array}{l}2.632 \\
(0.262)\end{array}$ & $\begin{array}{l}4.115 \\
(0.619)\end{array}$ & $\begin{array}{l}0.562 \\
(0.038)\end{array}$ & $\begin{array}{l}0.942 \\
(0.005)\end{array}$ & $<0.01$ & 0.97 & 132 & 1323 \\
\hline \multicolumn{10}{|l|}{ MPC } \\
\hline \multirow[t]{3}{*}{$\begin{array}{c}1997 \text { to } \\
2007\end{array}$} & Aggregate & $\begin{array}{l}5.150 \\
(0.301)\end{array}$ & $\begin{array}{l}4.944 \\
(1.584)\end{array}$ & $\begin{array}{l}2.364 \\
(0.538)\end{array}$ & $\begin{array}{l}0.950 \\
(0.015)\end{array}$ & & 0.98 & 126 & - \\
\hline & $\begin{array}{l}\text { Fixed } \\
\text { Effects }\end{array}$ & $\begin{array}{l}5.485 \\
(0.113)\end{array}$ & $\begin{array}{l}4.183 \\
(0.508)\end{array}$ & $\begin{array}{l}1.947 \\
(0.189)\end{array}$ & $\begin{array}{l}0.936 \\
(0.006)\end{array}$ & & 0.96 & 125 & 992 \\
\hline & $\begin{array}{l}\text { Random } \\
\text { Effects }\end{array}$ & $\begin{array}{l}5.006 \\
(0.113)\end{array}$ & $\begin{array}{l}4.058 \\
(0.488)\end{array}$ & $\begin{array}{l}2.080 \\
(0.158)\end{array}$ & $\begin{array}{l}0.942 \\
(0.005)\end{array}$ & 0.046 & 0.97 & 125 & 1046 \\
\hline \multirow[t]{3}{*}{$\begin{array}{c}1997 \text { to } \\
2008\end{array}$} & Aggregate & $\begin{array}{l}5.285 \\
(0.336)\end{array}$ & $\begin{array}{l}6.196 \\
(1.881)\end{array}$ & $\begin{array}{l}2.666 \\
(0.595)\end{array}$ & $\begin{array}{l}0.948 \\
(0.015)\end{array}$ & & 0.98 & 138 & - \\
\hline & $\begin{array}{l}\text { Fixed } \\
\text { Effects }\end{array}$ & $\begin{array}{l}5.487 \\
(0.233)\end{array}$ & $\begin{array}{l}5.663 \\
(0.592)\end{array}$ & $\begin{array}{l}2.068 \\
(0.195)\end{array}$ & $\begin{array}{l}0.935 \\
(0.006)\end{array}$ & & 0.96 & 137 & 1187 \\
\hline & $\begin{array}{l}\text { Random } \\
\text { Effects }\end{array}$ & $\begin{array}{l}5.181 \\
(0.109)\end{array}$ & $\begin{array}{l}5.438 \\
(0.585)\end{array}$ & $\begin{array}{l}2.388 \\
(0.188)\end{array}$ & $\begin{array}{l}0.942 \\
(0.005)\end{array}$ & $<0.01$ & 0.96 & 137 & 1187 \\
\hline \multicolumn{10}{|c|}{ Riksbank's Executive Board } \\
\hline \multirow[t]{3}{*}{$\begin{array}{l}1999 \text { to } \\
2009\end{array}$} & Aggregate & $\begin{array}{l}2.057 \\
(0.427)\end{array}$ & $\begin{array}{l}3.706 \\
(1.680)\end{array}$ & $\begin{array}{l}2.472 * \\
(0.800)\end{array}$ & $\begin{array}{l}0.949^{*} \\
(0.024)\end{array}$ & & 0.96 & 132 & - \\
\hline & $\begin{array}{l}\text { Fixed } \\
\text { Effects }\end{array}$ & $\begin{array}{l}1.924 \\
(0.335)\end{array}$ & $\begin{array}{l}2.576 \\
(0.771)\end{array}$ & $\begin{array}{l}1.340^{*} \\
(0.230)\end{array}$ & $\begin{array}{l}0.875^{*} \\
(0.023)\end{array}$ & & 0.90 & 132 & 381 \\
\hline & $\begin{array}{l}\text { Random } \\
\text { Effects }\end{array}$ & $\begin{array}{l}2.613 \\
(0.230)\end{array}$ & $\begin{array}{l}1.937 \\
(0.786)\end{array}$ & $\begin{array}{l}1.370 \\
(0.275)\end{array}$ & $\begin{array}{l}0.865 \\
(0.029)\end{array}$ & $<0.01$ & 0.88 & 132 & 249 \\
\hline
\end{tabular}

Notes: Standard errors in brackets. Prob.: Hausman specification test selects the random effects model, if the probability exceeds $5 \%$ - otherwise the fixed effects model is sufficient. ${ }^{*}$ ) Wald tests reject that parameters are equal at $5 \%$ level. 
